\title{
1 Effect of rainfall and swath density on dry matter and \\ 2 composition change during drying of switchgrass and \\ 3 corn stover
}

\author{
Amit Khanchi*, Stuart Birrell \\ Department of Agricultural and Biosystems Engineering \\ Iowa State University \\ Ames, Iowa, 50011, USA \\ * Corresponding author, Email address: amit@iastate.edu
}

Abstract

During field drying, crops can be subjected to rainfall losses due to leaching, respiration and mechanical treatments. The objective of this study was to measure the impact of rainfall amount (8 to $75 \mathrm{~mm}$ ) and crop density (0.8 to 2.6 (corn stover), 1 to 3.2 (switchgrass) $\mathrm{kg}_{\text {[DM] m}}{ }^{-2}$ ) on dry matter and composition change of corn stover (CS) and switchgrass. CS and switchgrass lost 0.3 to $4.7 \%$ and 0.2 to $2.8 \%$ as leaching loss from 8 to $75 \mathrm{~mm}$ of rainfall, respectively. After the incubation period of $48 \mathrm{~h}$, the dry matter loss increased to 7.2 to $9.8 \%$ (CS) and 2.6 to $6.1 \%$ (switchgrass) from 8 to $75 \mathrm{~mm}$ of rainfall, respectively. Water soluble portion of CS and switchgrass was more severely affected than the fibre portion. Corn stover, being more exposed to rainfall in low density (LD) swaths, lost 56.7\% ash content, compared to $19 \%$ in high density (HD) swaths. In CS, a significant decrease of K ( 10.2 to $63.8 \%$ ) and Mg (5.6 to 41.7\%) was observed with greater reductions in LD swaths compared to HD swaths. Similarly, a significant decrease in K (6.2 to 23.0\%) and Mg (5.1 to 17\%) content was observed in switchgrass but it was less prominent than CS.

Keywords. Rainfall loss, leaching loss, dry matter loss, extractive loss, mineral change, fibrechange.

\section{1. Introduction}

28 Evaluating and quantifying various sources of loss during the biomass supply chain is crucial for the economical production of biofuels. A considerable loss of 15 to $30 \%$ dry matter or yield has been reported for different crops during harvesting operations (Kallis, Susini, \& Oakey, 2013; Sultana \& Kumar, 2012; Valtere, Kirsanovs, \& Zandeckis, 2015). Crops are often dried in windrows (Fig. 1) to decrease the moisture content for safe storage as well as reduced 
more solar radiation and lose moisture quicker than high density windrows. Density of swaths can be controlled by adjusting windrow forming shields located on the back of the mower conditioner or by using tedders, which spread the crop in the field. The common sources of dry matter loss during field drying include plant and microbial respiration, rain damage, or mechanical loss due to shattering or dropping of crop material by the machinery.

The equipment used, time of harvest, harvesting operations followed, and weather conditions influence the extent of losses during the harvesting process (Rotz, 1995). Losses caused by rain varywidely and dependent on crop and environmental factors. Direct loss due to rainfall includes

42 leaf loss and leaching loss. Leaf loss is caused by the impact of raindrops on the crop, which removes some leaves from the stems and thus are not picked up by the baler. Leaching loss occurs when the soluble portion of the crop is washed into the soil. Both losses result in loss of dry matter from the biomass. The leaching loss is often quantified together with respiration loss. conditions after rainfall also govern total dry matter loss. If drying conditions are favourable, the moisture content of the crop drops quickly, limiting the damage caused by rain and microbial

52 respiration. However, under unfavourable drying conditions, dry matter loss of up to 50\% has

53 been reported from conditioned crops (Rotz, 1995). The effect of rainfall amount and crop

54 characteristics are difficult to measure and control in field conditions under natural rainfall.

55 Artificial rain showers offer much more control and flexibility for performing experiments.

56 However, experiments which use artificial rain showers tend to show lower losses than natural 
57 rainfall due to the difference in rainfall duration and the kinetic energy of raindrops (Rotz, 1995).

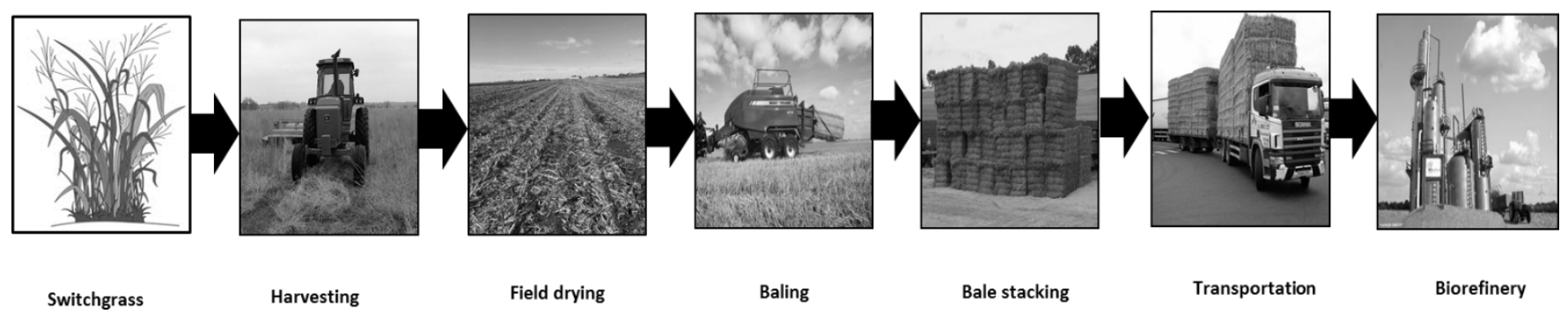

Fig 1. Switchgrass handling steps from harvest to transportation to a biorefinery

60 It is also important to quantify the constituents lost during rainfall. Rainfall leachesthe more

61 soluble portion and can remove some of the minerals or ash in the biomass. The constituents that

62 get dissolved as water soluble extractives include inorganic salts, non-structural sugars, gums,

63 starches, colouring matter and tannins (Sluiter, Ruiz, Scarlata, \& Templeton, 2008;

64 Thammasouk, Tandjo, \& Penner, 1997). Cold water $\left(23^{\circ} \mathrm{C}\right)$ removes tannins, gums, sugar, and

65 colouring matter from lignocellulosic biomass. Hot water $\left(100^{\circ} \mathrm{C}\right)$ extractions can remove starch

66 in combination to constituents removed with cold water (Sluiter, Ruiz, Scarlata, \& Templeton,

67 2008; Thammasouk, Tandjo, \& Penner, 1997). It is crucial to minimise the dry matter lost

68 during the post-harvest supply of biomass to biorefineries as it can significantly increase the cost

69 of fuel produced from biomass.

70 Researchers have studied the diverse factors which influence the loss caused by rainfall during

71 field drying of forage crops. Kormos and Chestnutt(1968) evaluated the effect of rainfall amount,

72 mechanical treatment, and stage of maturity on dry matter loss from ryegrass and white clover.

73 They reported that after a one-day wilting period, dry matter loss increased from $2.9 \%$ to $4.6 \%$

74 with an increase in rainfall amount from 6 to $25 \mathrm{~mm}$, respectively. However, the loss was not

75 significantly influenced by the frequency of rain or duration of the wilting period prior to the 
rainfall event. Additionally, more losses were observed inconditioned grass (4.6\%) compared to

77 unconditioned grass (2.4\%) and the extent of loss was dependent on the degree of laceration.

78 Grass lying in higher densities also suffered losses of $3.0 \%$, compared to $1.6 \%$ when the grass

79 was spread in thinner layers. Fonnesbeck, Hernandez, Kaykay, and Saiady(1986) estimated the

80 yield and nutrient losses due to rainfall on field drying alfalfa hay. They reported dry matter loss

81 of $4.6 \%$ and $9.7 \%$ from rainfall amounts of 5 and $20 \mathrm{~mm}$, respectively. They also reported that

$8220 \mathrm{~mm}$ of simulated rainfall reduced available carbohydrates from $27.3 \%$ to $24.3 \%$ and soluble

83 ash from 9.5\% to 9.0\%. Models for leaf and leaching loss were also developed by Rotz(1995)

84 and McGechan (1989) based on past data collected for forage crops. Numerical relationships

85 were established between leaching loss, crop moisture content, amount of rainfall, concentration

86 of soluble cell content, runoff rainfall, and conditioning factors. These studies confirm that

87 rainfall had a significant impact on dry matter and chemical composition of the agricultural

88 crops. However, there is minimal information available on losses occurring during a rainfall

89 event from switchgrass and corn stover. The quality parameters for the bioenergy crops also vary

90 from the crops that are utilized for animal feed purposes. Therefore, it is crucial to investigate

91 rainfall losses in the supply chain to get realistic costs for delivering biomass to biorefineries.

92 The specific objective of this study is to estimate the impact of rainfall amount and crop density

93 on dry matter loss and compositional changes from switchgrass and CS.

\section{2. Materials and method}

95 2.1. Crop collection:

CS and switchgrass were collected from agricultural farms owned by Iowa State

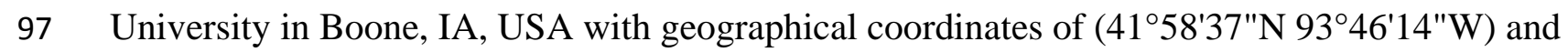

98 (4200'37"N, 9344'43"W), respectively. CS was collected and packed as round bales after a 
99 single pass harvest operation in which CS was directly fed into a round baler after harvest

100 without making any ground contact. Immediately after harvest, samples were collected from

101 several round bales randomly located in the field. Samples were filled in plastic bags and stored

102 in a cold storage at $5{ }^{\circ} \mathrm{C}$ until they were kept under an artificial rain shower for analysis.

104 in cold storage at $5{ }^{\circ} \mathrm{C}$ until subjected to the rainfall treatment. After frost, the samples were

105 harvested when weather permitted and surplus samples were stored in cold storage at $5{ }^{\circ} \mathrm{C}$ until

106 further analysis. The detailed sample collection schedule and initial moisture content for CS and

107 switchgrass is presented in Table 1.

Table 1. Dates of corn stover and switchgrass collection with variation in initial moisture content. The range of dry matter density and rainfall tested during the experiments is also shown below

\begin{tabular}{lccc}
\hline $\begin{array}{l}\text { Corn Stover } \\
\text { collection date }\end{array}$ & $\begin{array}{c}\text { Moisture content at } \\
\text { harvest (\%) }\end{array}$ & Switchgrass collection date & $\begin{array}{c}\text { Moisture content at } \\
\text { harvest (\%) }\end{array}$ \\
\hline 17th Aug 2013 & 31.2 & 7th Nov 2013 & 40.5 \\
& 11th Nov 2013 & 31.1 \\
& 14th Nov 2013 & 21.0 \\
& 18th Nov 2013 & 22.1 \\
& 10th Feb 2014 & 13.1 \\
& 13th Feb 2014 & 13.1 \\
& 17th Feb 2014 & 13.0 \\
\hline
\end{tabular}

Range of dry matter density tested during the rainfall experiments

\begin{tabular}{lccc}
\hline Crop & $\begin{array}{c}\text { Low dry matter density } \\
\text { (LD) }\end{array}$ & $\begin{array}{c}\text { Medium dry matter density } \\
(\mathrm{MD})\end{array}$ & $\begin{array}{c}\text { High dry matter density } \\
(\mathrm{HD})\end{array}$ \\
\hline & & $\left(\mathrm{kgm}^{-2}\right)$ & \\
\cline { 2 - 4 } Corn Stover & 0.8 & 1.3 & 2.6 \\
Switchgrass & 1.0 & 1.6 & 3.2 \\
\hline
\end{tabular}


Range of rainfall amount tested during the experiment

Rain fall (mm) 8, 25, 50, 75

\subsection{Experimental plan, design, and analysis:}

A $4 \times 3$ factorial design with four levels of rainfall amount and three levels of swath density was used for experimentation (Table 1). The experiment was repeated three times

112 between $24^{\text {th }}$ October 2013 and $10^{\text {th }}$ March 2014. During the experiments, switchgrass and CS 113 were placed into low (LD), medium (MD) and high density (HD) windrows under the artificial 114 rain shower. The rainfall simulator used in thisstudy was similar tothat developed by Norton and 115 Savabi(Norton \& Savabi, 2010) and is discussed in detail in their paper under the development 116 of the portable continuously variable intensity linear simulator. The height of the nozzles were 117 set to $2.4 \mathrm{~m}$ and the pressure in each line was $41 \mathrm{kPa}$.

118 The dry density of switchgrass placed in LD, MD, and HD windrows were 0.97, 1.6, and $3.2 \mathrm{~kg}$ $119 \mathrm{~m}^{-2}$, respectively. Similarly, dry density of CS placed in LD, MD and HD windrows were 0.8, $120 \quad 1.3$ and $2.6 \mathrm{~kg} \mathrm{~m}^{-2}$, respectively. Although, the experimental setup and design were similar for 121 both switchgrass and CS experiments, they were performed on separate occasionsand were 122 independent of each other.

123 Switchgrass and CS samples were placed on 75.7 l storage capacity plastic containers with a 124 layer of muslin cloth and wire mesh under the crop sample, respectively. Rain water applied 125 usingthe rainfall simulatorpassedthrough the crop, muslin cloth, and wire mesh, and then was 126 collected in the storage container. Wire mesh provided the strength to hold the crop above the 127 container and the muslin cloth simulated a saturated soil layer as well as helped retain the fines 128 from dropping into the runoff water collected in the storage container. Different densities were 
129 simulated by adding varying amounts of crop material to the same surface area. The switchgrass 130 and CS were subjected to four levels of rainfall amount (8, 25, 50 and $75 \mathrm{~mm})$ using the rainfall 131 shower. All experiments were conducted at a moderate rainfall intensity of $8 \mathrm{~mm} \mathrm{hr}^{-1}$.

132 During each experiment, two trays of LD, MD, and HD swath were kept under the rainfall 133 shower. After subjecting switchgrass and CS to rainfall treatment, trays were left undisturbed for 13448 hat $21{ }^{\circ} \mathrm{C}$ and $60 \% \mathrm{Rh}$ (incubation period) to simulate the field drying period after a rainfall 135 event. After the incubation period of $48 \mathrm{~h}$, one tray was weighed and kept in an oven at $103{ }^{\circ} \mathrm{C}$ 136 for $24 \mathrm{~h}$ for dry matter loss analysis and the other was dried at a lower temperature of $60{ }^{\circ} \mathrm{C}$ for $13772 \mathrm{~h}$ and used for compositional analysis (ASAE, 2003). Losses were measured by the following 138 methods: 1) measuring the total solids in the runoff water collected in the storage container 139 (leaching loss), 2) measuring the loss in the water soluble portion of switchgrass by measuring 140 the water soluble extractives before the rainfall treatment and after the $48 \mathrm{~h}$ incubation period, 141 and 3) measuring the dry matter loss after the incubation period of $48 \mathrm{~h}$. The leaching (LL), 142 water solubleextractive (WSEL), and dry matter (DML) loss were calculated in percent by Eq.1, 1432 and 3, respectively.

$$
L L=\frac{T S_{\text {runoff }}}{D M_{i}} \times 100
$$

$$
W S E L=\frac{W S E_{i}-W S E_{f}}{W S E_{i}} \times 100
$$

$$
D M L=\frac{D M_{i}-D M_{f}}{D M_{i}} \times 100
$$

$147 T S_{\text {runoff }}$ is total solids in runoff water, $D M_{i}$ and $D M_{f}$ are the initial and final dry matter content, and $148 W S E_{i}$ and $W S E_{f}$ are the initial and final water soluble extractive content, respectively. To 149 calculate total solids in runoff water, a small portion of runoff water $(190 \mathrm{ml})$ was dried at $60{ }^{\circ} \mathrm{C}$ 150 to constant weight $\left(\mathrm{ODW}_{190 \mathrm{ml}}\right)$ and then it was multiplied by the total volume of runoff water 
151 collected in the container given by Eq.4.

$$
T S_{\text {runoff }}=\frac{O D W_{190 \mathrm{ml}}}{190} \times \text { volume of runoff water }
$$

154 WSE of biomass in the initial and final sample was measured by the Soxhlet method and the samples were extracted with HPLC grade water for 10 h(Sluiter, Ruiz, Scarlata, \& Templeton, 156 2008). Before and after rainfall treated and incubated samples were also subjected to 157 compositional analysis of mineral, ash, and fibre content. The samples for compositional analysis 158 were sent to Agsource Laboratories in Umatilla, OR, USA. Dried samples were ground to $1 \mathrm{~mm}$ 159 using a knife mill and then passed through a $1.0 \mathrm{~mm}$ screen before the samples were subjected to water soluble extractives, ADL (Acid Detergent Lignin), ADF (Acid Detergent Fibre), minerals, 161 and ash (Jung \& Lamb, 2004; Sluiter et al., 2008) analysis. Hemicellulose content is often 162 calculated as the difference between NDF and ADF fraction whereas, cellulose is calculated as 163 the difference between ADF and ADL fraction (Jung \& Lamb, 2004). Lignin found in cell walls 164 was determined by using standard ADL procedures (Mertens, 1992; Van Soest, Robertson, \& 165 Lewis, 1991). Ash content was measured by following National Renewable Energy Laboratory 166 (NREL) Laboratory Analytical Procedures (LAP) for determination of ash in biomass (Sluiter et 167 al., 2008). Mineral analysis was performed using both wet chemistry and spectrometry 168 techniques explained in detail by Jones and Case (1990). The change in mineral, ash and fibre 169 content after the rainfall and incubation period given in Tables 3, 4, 5 and 6 was calculated 170 byEq.5.

$$
\% \text { Change }=\frac{C_{i} \times D M_{i}-C_{f} \times D M_{f}}{C_{i} \times D M_{i}} \times 100
$$

172 Where $C_{i}$ and $C_{f}$ are the initial concentration before rainfall treatment and final concentration 
173 after the incubation period of the constituent being analysed for change.

174

175

176

177

178

179

180

181

182

183

184

185

186

187

188

189

190

191

192

193

194

\subsection{Statistics}

Leaching loss, extractive loss, dry matter loss, and compositional changes were analysed by split plot design using PROC Mixed in SAS 9.4 (SAS Institute, 2015). Rainfall level, swath density, and interaction of rainfall and swath density were treated as fixed effects and replication, and interaction of replication with rainfall level were treated as random effects.

\section{Results and discussion:}

\subsection{Leaching loss:}

Generally, greater leaching loss is expected with increasing rainfall amounts. In the present study, when the rainfall amount increased from 8 to $75 \mathrm{~mm}$, leaching loss increased by 93\% and 85\% in switchgrass and CS, respectively. Crop manipulation techniques such as crop

conditioning and drying the crop in varying swath densities impacted the losses during rainfall events. In the present study, switchgrass had $25 \%$ and $43.8 \%$ greater leaching loss when placed in MD and LD swaths compared to HD swaths, respectively (Table 2). Similarly, a significant effect of swath density was observed in which CS placed in LD swaths had 43.3\% greater leaching loss compared to HD swaths. Switchgrass and CS placed in LD swaths were highly exposed to rainfall, whereas, top layers in HD swaths provide protection to the underlying layers.

During harvest, a conditioning treatment is often applied to crops to increase the drying rate.

These mechanical operations break the outer layer of the biomass and expose the soluble components to leaching loss.

Collins (1983) also reported a leaching and respiration loss of 3.6 to $4.3 \%$ from untreated alfalfa which increased to 4.9 to $6.3 \%$ after $25 \mathrm{~mm}$ of rainfall and a $96 \mathrm{~h}$ incubation period. A model 
195 developed by Rotz(1995) estimated leaching losses of 2.2, 6.8 and 13\% from 8, 25 and 50 mm of 196 rainfall, respectively. The data used to develop the model by Rotz(1995) included both leaching 197 and respiration loss because they were difficult to measure separately (Rucker \& Knabe, 1977).

198 However, in the present study leaching loss includes only the soluble solids leached out after the 199 rainfall and thus, are less than reported losses in other studies.

Table 2. Influence of rainfall amount and swath density on leaching, extractive and dry matter loss from switchgrass

\begin{tabular}{|c|c|c|c|c|c|c|c|}
\hline \multirow[b]{2}{*}{$\begin{array}{l}\text { Rainfall } \\
\text { amount }\end{array}$} & \multirow{3}{*}{ Density } & \multicolumn{3}{|c|}{ Switchgrass } & \multicolumn{3}{|c|}{ Corn Stover } \\
\hline & & $\begin{array}{l}\text { Leaching } \\
\text { Loss }^{\mathrm{z}}\end{array}$ & $\begin{array}{c}\text { WSE }^{\alpha} \\
\text { Loss }\end{array}$ & $\begin{array}{l}\text { Dry Matter } \\
\text { loss }\end{array}$ & $\begin{array}{l}\text { Leaching } \\
\text { Loss }\end{array}$ & $\begin{array}{l}\text { WSE }^{\alpha} \\
\text { Loss }\end{array}$ & $\begin{array}{l}\text { Dry Matter } \\
\text { loss }\end{array}$ \\
\hline$(\mathrm{mm})$ & & & & $(\%$ & & & \\
\hline 8 & $\mathrm{LD}$ & $0.3^{\mathrm{a}}$ & $2.9^{\mathrm{bcd}}$ & $3.2^{\mathrm{a}}$ & $0.6^{\mathrm{a}}$ & $0.6^{\mathrm{C}}$ & $9.4^{\mathrm{a}}$ \\
\hline 8 & MD & $0.2^{\mathrm{a}}$ & $2.0^{\mathrm{d}}$ & $2.6^{\mathrm{a}}$ & $0.3^{\mathrm{a}}$ & $1.9^{\mathrm{bc}}$ & $8.8^{\mathrm{a}}$ \\
\hline 8 & HD & $0.1^{\mathrm{ab}}$ & $2.2^{\mathrm{cd}}$ & $2.0^{\mathrm{a}}$ & $0.5^{\mathrm{ab}}$ & $2.0^{\mathrm{C}}$ & $7.7^{\mathrm{a}}$ \\
\hline 25 & LD & $0.8^{\mathrm{ab}}$ & $2.5^{\mathrm{cd}}$ & $2.7^{\mathrm{a}}$ & $2.4^{\mathrm{b}}$ & $3.9^{\mathrm{ab}}$ & $9.8^{\mathrm{a}}$ \\
\hline 25 & $\mathrm{MD}$ & $0.6^{\mathrm{abc}}$ & $4.3^{\mathrm{abc}}$ & $1.9^{\mathrm{ab}}$ & $1.9^{\mathrm{cb}}$ & $3.9^{\mathrm{ab}}$ & $8.4^{\mathrm{a}}$ \\
\hline 25 & HD & $0.4^{\mathrm{bc}}$ & $3.6^{\mathrm{abcd}}$ & $4.6^{\mathrm{ab}}$ & $1.4^{\mathrm{cb}}$ & $3.8^{\mathrm{ab}}$ & $9.3^{\mathrm{a}}$ \\
\hline 50 & LD & $1.9^{\mathrm{bcd}}$ & $4.1^{\mathrm{abcd}}$ & $5.6^{\mathrm{abc}}$ & $4.2^{\mathrm{cb}}$ & $4.2^{\mathrm{a}}$ & $8.0^{\mathrm{a}}$ \\
\hline 50 & MD & $1.3^{\mathrm{bcd}}$ & $4.1^{\mathrm{abcd}}$ & $4.1^{\mathrm{abc}}$ & $1.5^{\mathrm{cb}}$ & $4.5^{\mathrm{a}}$ & $9.8^{\mathrm{a}}$ \\
\hline 50 & HD & $0.6^{\text {bcde }}$ & $5.5^{\mathrm{a}}$ & $3.7^{\mathrm{abcd}}$ & $2.6^{\mathrm{bcd}}$ & $4.4^{\mathrm{a}}$ & $7.8^{\mathrm{a}}$ \\
\hline 75 & LD & $3.7^{\text {cde }}$ & $5.0^{\mathrm{ab}}$ & $6.4^{\mathrm{bcd}}$ & $4.7^{\mathrm{cd}}$ & $5.0^{\mathrm{a}}$ & $8.0^{\mathrm{a}}$ \\
\hline 75 & MD & $2.5^{\text {cde }}$ & $5.1^{\mathrm{ab}}$ & $5.9^{\mathrm{ebcd}}$ & $2.8^{\text {cde }}$ & $4.5^{\mathrm{a}}$ & $7.3^{\mathrm{a}}$ \\
\hline 75 & HD & $2.3^{\mathrm{de}}$ & $4.2^{\mathrm{abcd}}$ & $6.1^{\text {ecd }}$ & $2.3^{\text {cde }}$ & $3.5^{\mathrm{ab}}$ & $7.2^{\mathrm{a}}$ \\
\hline
\end{tabular}

Influence of swath density on leaching, extractives and dry matter loss from switchgrass. Data are pooled over rainfall amount
LD
$1.6^{\mathrm{a}}$
$3.6^{\mathrm{a}}$
$4.5^{\mathrm{a}}$
$3.0^{\mathrm{a}}$
$3.4^{\mathrm{a}}$
$8.8^{\mathrm{a}}$ 

MD
$1.2^{\mathrm{ab}}$
$3.8^{\mathrm{a}}$
$3.6^{\mathrm{a}}$
$1.6^{\mathrm{b}}$
$3.7^{\mathrm{a}}$
$8.6^{\mathrm{a}}$
HD
$0.9^{\mathrm{b}}$
$3.9^{\mathrm{a}}$
$4.1^{\mathrm{a}}$
$1.7^{\mathrm{b}}$
$3.2^{\mathrm{a}}$
$8.0^{\mathrm{a}}$

\begin{tabular}{|c|c|c|c|c|c|c|}
\hline \multicolumn{7}{|c|}{$\begin{array}{l}\text { Influence of rainfall amount on leaching, extractives and dry matter loss from switchgrass. Data ar } \\
\text { pooled over swath density }\end{array}$} \\
\hline 8 & $0.2^{\mathrm{C}}$ & $2.3^{\mathrm{C}}$ & $2.6^{\mathrm{C}}$ & $0.5^{\mathrm{C}}$ & $1.2^{b}$ & $8.6^{\mathrm{a}}$ \\
\hline 25 & $0.6^{\mathrm{bc}}$ & $3.5^{\mathrm{b}}$ & $3.1^{\mathrm{c}}$ & $1.9^{\mathrm{b}}$ & $3.9^{\mathrm{a}}$ & $9.1^{\mathrm{a}}$ \\
\hline 50 & $1.3^{\mathrm{b}}$ & $4.5^{\mathrm{ab}}$ & $4.5^{\mathrm{b}}$ & $2.8^{\mathrm{ab}}$ & $4.4^{\mathrm{a}}$ & $8.5^{\mathrm{a}}$ \\
\hline 75 & $2.8^{\mathrm{a}}$ & $4.7^{\mathrm{a}}$ & $6.1^{\mathrm{a}}$ & $3.3^{\mathrm{a}}$ & $4.3^{\mathrm{a}}$ & $7.5^{\mathrm{a}}$ \\
\hline
\end{tabular}

\footnotetext{
${ }^{\mathrm{Z}}$ Means within columns followed by different letters are significantly different at the $95 \%$ confidence level. LD, MD, and HD is defined as low density, medium density and high density, respectively. ${ }^{\alpha} \mathrm{WSE}$ is the water soluble extractive content, *Leaching loss, extractive loss, and dry matter loss were calculated by formulae given in Eqs.1, 2, and 3, respectively
}

\subsection{Water soluble extractive (WSE) loss:}

202 During rainfall, the water-soluble portion of biomass, generally termed as water soluble extractives, are more severely affected than the fibre portion. In this study, the extractives loss also included respiration losses caused by microbial spoilage during the incubation period in addition to the direct leaching loss discussed previously.

Switchgrass had an initial WSE content of 15.7\% before frost, which reduced to an average initial WSE content of $11.0 \%$ after frost. This change in initial WSE content was due to an increase in maturity of crop and frost could have caused some variability in the final results. Switchgrass lost 2-fold more WSE at a rainfall amount of 50 and $75 \mathrm{~mm}$ compared to $8 \mathrm{~mm}$ and were statistically different (Table 2). Constituents such as organic acids, inorganic anions and

211 cations, and oligomeric and free sugars have been reported in the water soluble extractive portion

212 of switchgrass (Chen, Mowery, Sevcik, Scarlata, \& Chambliss, 2010). Chen et al. (2010)

213 reported an extractive content of 15\% in switchgrass and free sugars (i.e. monomeric sugars plus 214 sucrose) were 18 to $27 \%$ of the dry weight of the water-soluble material. 
215 Averaged over densities, CS also lost 3.5-fold more WSE at and above $25 \mathrm{~mm}$ rainfall compared

216 to $8 \mathrm{~mm}$. This can be due to the extensive conditioning of CS which facilitated leaching and

217 respiration losses as inner tissues were exposed to rainfall and microbial growth. Being highly

218 conditioned, CS settled into a dense swath with minimum aeration between the crop tissues. The

219 protection offered by top layers in HD swaths during rainfall might be annulled by high

220 respiration loss during the incubation period. In another study on CS, water-soluble extractives

221 varied from 14.2\% (NREL ID: Kramer 33A14) to 26.7\% (NREL ID: 2302-115) of the oven dry

222 weight of different CS varieties (Kormos \& Chestnutt, 1968). Monosaccharides, glucose, and

223 fructose constituted $30-46 \%$ of the dry weight of water-soluble materials extracted from corn

224 stover varieties (Kormos \& Chestnutt, 1968). These results have significant technical and

225 economic implication on biomass for the bioethanol conversion process.

\section{3.3. Dry matter loss}

227 While WSE loss reflected loss in the water-soluble portion of biomass and dry matter loss

228 estimated losses in the overall dry matter of switchgrass and CS. On average, switchgrass lost 2.6

229 and $3.1 \%$ of dry matter at 8 and $25 \mathrm{~mm}$ of rainfall compared to 4.5 and $6.1 \%$ at 50 and $75 \mathrm{~mm}$ of

230 rainfall, respectively (Table 2). Kormos and Chestnutt(1968) reported a dry matter loss of 2.9,

2313.7 and $4.6 \%$ at $6.4,13$ and $25 \mathrm{~mm}$ after one day of wilting from ryegrass and white clover,

232 respectively. Fonnesbeck, Hernandez, Kaykay, and Saiady(1986) also reported a dry matter loss

233 of 4.6 and $9.7 \%$ from alfalfa hay from a rainfall amount of 5 and $20 \mathrm{~mm}$, respectively which

234 illustrates that dry matter loss can vary significantly with crop type.

235 CS also lost 7.2 to $9.8 \%$ dry matter after the rainfall and incubation period of 48 hours. However,

236 no statistical difference was observed between the treatments. The trend observed during

237 leaching loss was not carried over to dry matter loss which could be due to microbial respiration 
238 as discussed in the previous section. Even a small amount of rainfall was enough to encourage

239 microbial growth on conditioned CS samples. The air movement was minimal due to the

240 collapsed structure of the swath. This kept the CS samples wet throughout the incubation period.

241 Dry matter loss from the crop is also dependent on the duration of the incubation period. Collins

242 (1983) reported a dry matter loss of 53.8\% from alfalfa at rainfall and incubation periods of 62

$243 \mathrm{~mm}$ and 96 hours, respectively. Dry matter loss from CS can also vary with changes in duration

244 or environmental conditions during the drying period. Dry matter loss in CS is expected to be

245 greater than fine stem crops such as switchgrass which form an airy swath structure after

246 harvesting.

247 3.4. Mineral and ash content change

$248 \quad$ 3.4.1 Minerals

249 During rainfall, soluble minerals also leach with other water soluble components of biomass.

250 After the rainfall event, $\mathrm{P}, \mathrm{K}$, and Mg concentration in switchgrass decreased whereas, S, and Ca

251 concentration increased slightly (Table 3). A significant influence of swath density was observed

252 in $\mathrm{K}$ and Mg concentration after the rainfall treatment in switchgrass. K concentration decreased

253 by $23 \%$ in LD swaths compared to $6.2 \%$ in HD swaths. Similarly, Mg content decreased by $17 \%$

254 in LD swaths compared to 5.1\% in HD swaths. Additionally, a significant effect of rainfall

255 amount was observed on K content, with greater reductions at higher rainfall amounts.

256 Switchgrass lost $6.3 \% \mathrm{~K}$ at $8 \mathrm{~mm}$ rainfall compared to $22.3 \%$ at $75 \mathrm{~mm}$.

257 A more prominent effect of rainfall was observed on CS than switchgrass. CS lost 51.3\% K

258 content placed in exposed LD swaths compared to 28.2\% in HD swaths (Table 4). Similarly, a

259 reduction of 27.4, 19.5 and $14.2 \%$ in Mg content was observed when placed in LD, MD and HD

260 swaths, respectively. The rainfall amount also significantly affected the magnitude of K content 
261 leached during rainfall. A loss of $18.6 \%$ was observed at $8 \mathrm{~mm}$ compared to $51.2 \%$ at $75 \mathrm{~mm}$ of 262 rainfall from CS. As discussed previously, switchgrass and CS stems are highly exposed to 263 rainfall in LD swaths, resulting in greater losses of soluble constituents. P, K, and Mg are also 264 highly soluble in water (Mertens, 1992) therefore, these are expected to leach during rainfall. K, $265 \mathrm{Mg}$ and Ca ions were also detected in CS and switchgrass water extractives by Chen, Mowery, 266 Scarlata, and Chambliss (2007). They found that $\mathrm{K}^{+}$is the major cation that was contained in the 267 water extractive of CS and varied from 4.0 to10.9\% of the dry weight of water extractives. 
Table 3. Final ash and mineral content left in switchgrass after the rainfall treatment and percent change in composition compared to initial values

\begin{tabular}{|c|c|c|c|c|c|c|c|c|c|c|c|c|c|}
\hline $\begin{array}{l}\text { Rainfall } \\
(\mathrm{mm})\end{array}$ & Density & Ash & $\mathrm{S}$ & $\mathrm{P}$ & $\mathrm{K}$ & $\mathrm{Ca}$ & $\mathrm{Mg}$ & $\begin{array}{l}\text { Ash } \\
\text { change }\end{array}$ & $\begin{array}{l}\mathrm{S} \\
\text { change }\end{array}$ & $\begin{array}{l}\mathrm{P} \\
\text { change }\end{array}$ & $\begin{array}{l}\mathrm{K} \\
\text { change }\end{array}$ & $\begin{array}{l}\mathrm{Ca} \\
\text { change }\end{array}$ & $\begin{array}{l}\text { Mg } \\
\text { change }\end{array}$ \\
\hline & & \multicolumn{6}{|c|}{$\% \mathrm{db}^{\mathrm{Z}}$} & \multicolumn{6}{|c|}{$\%^{\mathrm{z}, *}$} \\
\hline 8 & LD & $5.6^{\mathrm{a}}$ & $0.049^{\mathrm{ab}}$ & $0.039^{\mathrm{a}}$ & $0.20^{\mathrm{a}}$ & $0.44^{\mathrm{abc}}$ & $0.14^{\mathrm{abc}}$ & $9.6^{\mathrm{a}}$ & $-16.1^{d}$ & $3.5^{\mathrm{a}}$ & $14.2^{\mathrm{abc}}$ & $-6.1^{\mathrm{a}}$ & $-4.5^{\text {cde }}$ \\
\hline 8 & MD & $6.8^{\mathrm{a}}$ & $0.046^{\mathrm{ab}}$ & $0.038^{\mathrm{a}}$ & $0.20^{\mathrm{a}}$ & $0.42^{\mathrm{bc}}$ & $0.15^{\mathrm{ab}}$ & $4.2^{\mathrm{a}}$ & $-8.8^{b c d}$ & $6.4^{\mathrm{a}}$ & $18.0^{\mathrm{abc}}$ & $-4.7^{\mathrm{a}}$ & $-10.5^{\mathrm{e}}$ \\
\hline 8 & HD & $6.6^{\mathrm{a}}$ & $0.048^{\mathrm{ab}}$ & $0.048^{\mathrm{a}}$ & $0.25^{\mathrm{a}}$ & $0.45^{\mathrm{abc}}$ & $0.15^{\mathrm{abc}}$ & $10.0^{\mathrm{a}}$ & $-13.0^{\mathrm{cd}}$ & $1.9^{\mathrm{a}}$ & $-2.8^{c}$ & $-13.7^{a}$ & $-7.4^{\mathrm{de}}$ \\
\hline 25 & LD & $5.1^{\mathrm{a}}$ & $0.043^{\mathrm{b}}$ & $0.054^{\mathrm{a}}$ & $0.26^{\mathrm{a}}$ & $0.44^{\mathrm{bc}}$ & $0.13^{\text {cdef }}$ & $16.7^{\mathrm{a}}$ & $10.9^{\mathrm{a}}$ & $7.3^{\mathrm{a}}$ & $15.7^{\mathrm{abc}}$ & $-1.3^{\mathrm{a}}$ & $16.5^{\mathrm{ab}}$ \\
\hline 25 & MD & $5.3^{\mathrm{a}}$ & $0.046^{\mathrm{b}}$ & $0.056^{\mathrm{a}}$ & $0.27^{\mathrm{a}}$ & $0.44^{\mathrm{abc}}$ & $0.13^{\mathrm{abcd}}$ & $15.6^{\mathrm{a}}$ & $4.8^{\mathrm{ab}}$ & $3.3^{a}$ & $16.5^{\mathrm{abc}}$ & $-1.0^{\mathrm{a}}$ & $12.9^{\mathrm{abc}}$ \\
\hline 25 & HD & $6.3^{\mathrm{a}}$ & $0.055^{\mathrm{a}}$ & $0.040^{\mathrm{a}}$ & $0.26^{\mathrm{a}}$ & $0.41^{\mathrm{c}}$ & $0.15^{\mathrm{a}}$ & $9.6^{\mathrm{a}}$ & $-11.7^{c d}$ & $6.4^{\mathrm{a}}$ & $17.0^{\mathrm{abc}}$ & $8.4^{\mathrm{a}}$ & $4.8^{\text {bcde }}$ \\
\hline 50 & LD & $6.4^{\mathrm{a}}$ & $0.050^{\mathrm{ab}}$ & $0.042^{\mathrm{a}}$ & $0.19^{\mathrm{a}}$ & $0.52^{\mathrm{abc}}$ & $0.11^{\mathrm{g}}$ & $15.3^{\mathrm{a}}$ & $-1.3^{a b c}$ & $3.8^{a}$ & $35.5^{a}$ & $7.0^{\mathrm{a}}$ & $28.8^{\mathrm{a}}$ \\
\hline 50 & MD & $7.5^{\mathrm{a}}$ & $0.052^{\mathrm{ab}}$ & $0.041^{\mathrm{a}}$ & $0.22^{\mathrm{a}}$ & $0.52^{\mathrm{abc}}$ & $0.12^{\text {defg }}$ & $9.7^{\mathrm{a}}$ & $-5.4^{b c d}$ & $7.0^{\mathrm{a}}$ & $24.9^{\mathrm{ab}}$ & $4.6^{\mathrm{a}}$ & $19.8^{\mathrm{ab}}$ \\
\hline 50 & HD & $7.8^{\mathrm{a}}$ & $0.052^{\mathrm{ab}}$ & $0.052^{\mathrm{a}}$ & $0.25^{\mathrm{a}}$ & $0.52^{\mathrm{abc}}$ & $0.13^{\mathrm{abcd}}$ & $9.6^{\mathrm{a}}$ & $-7.1^{\mathrm{bcd}}$ & $1.9^{\mathrm{a}}$ & $10.2^{b c}$ & $5.6^{a}$ & $10.9^{\mathrm{abcd}}$ \\
\hline 75 & LD & $6.7^{\mathrm{a}}$ & $0.053^{\mathrm{ab}}$ & $0.048^{\mathrm{a}}$ & $0.22^{\mathrm{a}}$ & $0.56^{\mathrm{a}}$ & $0.11^{\mathrm{fg}}$ & $10.5^{\mathrm{a}}$ & $-12.2^{\mathrm{cd}}$ & $5.4^{\mathrm{a}}$ & $36.4^{\mathrm{a}}$ & $-4.8^{\mathrm{a}}$ & $27.0^{\mathrm{a}}$ \\
\hline 75 & MD & $7.2^{\mathrm{a}}$ & $0.050^{\mathrm{ab}}$ & $0.049^{\mathrm{a}}$ & $0.19^{\mathrm{a}}$ & $0.54^{\mathrm{ab}}$ & $0.12^{\mathrm{efg}}$ & $10.2^{\mathrm{a}}$ & $-6.6^{b c d}$ & $2.3^{\mathrm{a}}$ & $29.6^{\mathrm{ab}}$ & $-1.0^{\mathrm{a}}$ & $23.8^{\mathrm{a}}$ \\
\hline 75 & HD & $6.5^{\mathrm{a}}$ & $0.054^{\mathrm{ab}}$ & $0.049^{\mathrm{a}}$ & $0.25^{\mathrm{a}}$ & $0.54^{\mathrm{ab}}$ & $0.13^{\text {bcde }}$ & $15.2^{\mathrm{a}}$ & $-14.4^{\mathrm{cd}}$ & $1.9^{\mathrm{a}}$ & $10.7^{b c}$ & $-1.9^{a}$ & $12.1^{\mathrm{abc}}$ \\
\hline
\end{tabular}

Influence of swath density on the mineral content of switchgrass. Data are pooled over rainfall amount

\begin{tabular}{|c|c|c|c|c|c|c|c|c|c|c|c|c|}
\hline LD & $6.0^{\mathrm{a}}$ & $0.049^{b}$ & $0.046^{\mathrm{a}}$ & $0.22^{b}$ & $0.49^{\mathrm{a}}$ & $0.12^{b}$ & $13.0^{\mathrm{a}}$ & $4.6^{\mathrm{ab}}$ & $5.0^{\mathrm{a}}$ & $23.0^{\mathrm{a}}$ & $-1.3^{\mathrm{a}}$ & $17.0^{\mathrm{a}}$ \\
\hline MD & $6.7^{\mathrm{a}}$ & $0.048^{\mathrm{b}}$ & $0.046^{\mathrm{a}}$ & $0.22^{b}$ & $0.48^{\mathrm{a}}$ & $0.13^{b}$ & $9.9^{\mathrm{a}}$ & $-4.0^{\mathrm{a}}$ & $4.8^{a}$ & $22.3^{\mathrm{a}}$ & $-0.5^{a}$ & $11.5^{\mathrm{ab}}$ \\
\hline
\end{tabular}


HD

$$
\begin{array}{lllll}
6.8^{\mathrm{a}} & 0.052^{\mathrm{a}} & 0.047^{\mathrm{a}} & 0.25^{\mathrm{a}} & 0.48^{\mathrm{a}}
\end{array}
$$

$0.14^{\mathrm{a}}$

$11.1^{\mathrm{a}}$

$-11.6^{\mathrm{b}} \quad 3.0^{\mathrm{a}}$

$6.2^{\mathrm{b}}$

$-0.41^{\mathrm{a}}$

$5.1^{b}$

Influence of rainfall amounts on the mineral content of switchgrass. Data are pooled over swath density

\begin{tabular}{|c|c|c|c|c|c|c|c|c|c|c|c|c|}
\hline 8 & $6.3^{\mathrm{a}}$ & $0.048^{\mathrm{a}}$ & $0.042^{\mathrm{a}}$ & $0.22^{\mathrm{a}}$ & $0.43^{\mathrm{a}}$ & $0.14^{\mathrm{a}}$ & $7.9^{\mathrm{a}}$ & $-12.6^{b}$ & $4.0^{a}$ & $6.3^{b}$ & $-8.2^{\mathrm{a}}$ & $-7.5^{b}$ \\
\hline 25 & $5.6^{\mathrm{a}}$ & $0.048^{\mathrm{a}}$ & $0.050^{\mathrm{a}}$ & $0.26^{\mathrm{a}}$ & $0.43^{\mathrm{a}}$ & $0.14^{\mathrm{a}}$ & $14.0^{\mathrm{a}}$ & $1.4^{\mathrm{a}}$ & $5.7^{\mathrm{a}}$ & $16.4^{\mathrm{ab}}$ & $2.1^{\mathrm{a}}$ & $11.4^{\mathrm{a}}$ \\
\hline 50 & $7.2^{\mathrm{a}}$ & $0.052^{\mathrm{a}}$ & $0.045^{\mathrm{a}}$ & $0.21^{\mathrm{a}}$ & $0.52^{\mathrm{a}}$ & $0.12^{\mathrm{b}}$ & $11.5^{\mathrm{a}}$ & $-4.6^{\mathrm{ab}}$ & $4.2^{\mathrm{a}}$ & $23.5^{\mathrm{a}}$ & $5.7^{\mathrm{a}}$ & $19.9^{a}$ \\
\hline 75 & $6.8^{\mathrm{a}}$ & $0.052^{\mathrm{a}}$ & $0.048^{\mathrm{a}}$ & $0.22^{\mathrm{a}}$ & $0.55^{\mathrm{a}}$ & $0.12^{b}$ & $12.0^{\mathrm{a}}$ & $-11.1^{b}$ & $3.2^{\mathrm{a}}$ & $22.3^{\mathrm{a}}$ & $-2.6^{a}$ & $20.9^{a}$ \\
\hline
\end{tabular}

${ }^{\mathrm{Z}}$ Means within columns followed by different letters are significantly different at the 95\% confidence level. LD, MD, and HD is defined as low density, medium density, and high density, respectively. $* \%$ change is calculated by formulae, $\%$ Change $=$ $\frac{C_{i} \times D M_{i}-C_{f} \times}{C_{i} \times D M_{i}} \times 100$, where, $\mathrm{C}$ and $\mathrm{DM}$ are the concentration and dry matter of the constituent being analysed, and subscriptsi and $f$ are the initial and final values 
Table 4. Final ash and mineral content left in corn stover after the rainfall treatment and percent change in composition compared to initial values

\begin{tabular}{|c|c|c|c|c|c|c|c|c|c|c|c|c|c|}
\hline $\begin{array}{l}\text { Rainfall } \\
(\mathrm{mm})\end{array}$ & Density & Ash & $\mathrm{S}^{\mathrm{Z}}$ & $\mathrm{P}$ & $\mathrm{K}$ & $\mathrm{Ca}$ & $\mathrm{Mg}$ & $\begin{array}{c}\text { Ash } \\
\text { change }\end{array}$ & $\begin{array}{c}\mathrm{S} \\
\text { change }\end{array}$ & $\begin{array}{c}\mathrm{P} \\
\text { change }\end{array}$ & $\begin{array}{c}\text { K } \\
\text { change }\end{array}$ & $\begin{array}{c}\text { Ca } \\
\text { change }\end{array}$ & $\begin{array}{c}\mathrm{Mg} \\
\text { change }\end{array}$ \\
\hline & & \multicolumn{6}{|c|}{$\% \mathrm{db}^{\mathrm{Z}}$} & \multicolumn{6}{|c|}{$\%^{\mathrm{z},{ }^{*}}$} \\
\hline 8 & LD & $4.6^{\mathrm{b}}$ & $0.06^{\mathrm{a}}$ & $0.05^{\mathrm{a}}$ & $0.61^{\mathrm{abc}}$ & $0.45^{\text {bcd }}$ & $0.20^{\mathrm{a}}$ & $54.1^{\mathrm{a}}$ & $-16.4^{\mathrm{a}}$ & $-40.1^{\mathrm{a}}$ & $30.9^{\text {cdef }}$ & $3.6^{\mathrm{abc}}$ & $6.3^{\mathrm{b}}$ \\
\hline 8 & MD & $4.4^{\mathrm{b}}$ & $0.05^{\mathrm{a}}$ & $0.05^{\mathrm{a}}$ & $0.80^{\mathrm{a}}$ & $0.38^{d}$ & $0.19^{\mathrm{a}}$ & $55.3^{\mathrm{a}}$ & $-1.7^{\mathrm{a}}$ & $-33.9^{\mathrm{a}}$ & $10.2^{\mathrm{g}}$ & $17.2^{\mathrm{a}}$ & $10.2^{\mathrm{b}}$ \\
\hline 8 & HD & $8.3^{\mathrm{a}}$ & $0.06^{\mathrm{a}}$ & $0.06^{\mathrm{a}}$ & $0.75^{\mathrm{ab}}$ & $0.40^{\mathrm{cd}}$ & $0.19^{\mathrm{a}}$ & $14.1^{\mathrm{b}}$ & $0.1^{\mathrm{a}}$ & $-48.3^{a}$ & $14.6^{\mathrm{fg}}$ & $12.8^{\mathrm{a}}$ & $5.6^{\mathrm{b}}$ \\
\hline 25 & LD & $4.2^{\mathrm{b}}$ & $0.06^{\mathrm{a}}$ & $0.06^{\mathrm{a}}$ & $0.44^{\mathrm{cd}}$ & $0.47^{\mathrm{abc}}$ & $0.14^{\mathrm{ab}}$ & $59.8^{\mathrm{a}}$ & $-9.8^{\mathrm{a}}$ & $-41.7^{\mathrm{a}}$ & $49.0^{\mathrm{abc}}$ & $2.7^{\mathrm{abc}}$ & $33.0^{\mathrm{ab}}$ \\
\hline 25 & MD & $3.8^{\mathrm{b}}$ & $0.06^{\mathrm{a}}$ & $0.06^{\mathrm{a}}$ & $0.68^{\mathrm{abc}}$ & $0.41^{\mathrm{cd}}$ & $0.15^{\mathrm{ab}}$ & $61.9^{\mathrm{a}}$ & $-37.6^{\mathrm{a}}$ & $-45.2^{\mathrm{a}}$ & $20.0^{\text {efg }}$ & $11.7^{\mathrm{a}}$ & $24.7^{\mathrm{ab}}$ \\
\hline 25 & HD & $7.6^{\mathrm{a}}$ & $0.06^{\mathrm{a}}$ & $0.05^{\mathrm{a}}$ & $0.67^{\mathrm{abc}}$ & $0.40^{\mathrm{cd}}$ & $0.16^{\mathrm{ab}}$ & $23.9^{b}$ & $-13.0^{\mathrm{a}}$ & $-40.7^{\mathrm{a}}$ & $22.7^{\text {defg }}$ & $13.6^{\mathrm{a}}$ & $22.6^{\mathrm{ab}}$ \\
\hline 50 & LD & $4.4^{\mathrm{b}}$ & $0.07^{\mathrm{a}}$ & $0.06^{\mathrm{a}}$ & $0.33^{d}$ & $0.54^{\mathrm{a}}$ & $0.15^{\mathrm{ab}}$ & $55.1^{\mathrm{a}}$ & $-21.5^{\mathrm{a}}$ & $-58.7^{\mathrm{a}}$ & $61.7^{\mathrm{ab}}$ & $-16.5^{c}$ & $28.7^{\mathrm{ab}}$ \\
\hline 50 & MD & $3.8^{\mathrm{b}}$ & $0.07^{\mathrm{a}}$ & $0.06^{\mathrm{a}}$ & $0.53^{\text {bcd }}$ & $0.46^{\mathrm{bcd}}$ & $0.18^{\mathrm{ab}}$ & $62.1^{\mathrm{a}}$ & $-23.4^{\mathrm{a}}$ & $-59.4^{\mathrm{a}}$ & $39.2^{\text {cde }}$ & $1.7^{\mathrm{abc}}$ & $14.5^{\mathrm{ab}}$ \\
\hline 50 & HD & $9.5^{\mathrm{a}}$ & $0.07^{\mathrm{a}}$ & $0.06^{\mathrm{a}}$ & $0.57^{\text {abcd }}$ & $0.44^{\text {bcd }}$ & $0.19^{\mathrm{a}}$ & $11.3^{b}$ & $-6.7^{\mathrm{a}}$ & $-50.8^{\mathrm{a}}$ & $34.0^{\text {cdef }}$ & $4.9^{\mathrm{ab}}$ & $6.3^{\mathrm{b}}$ \\
\hline 75 & LD & $4.2^{\mathrm{b}}$ & $0.07^{\mathrm{a}}$ & $0.05^{\mathrm{a}}$ & $0.31^{d}$ & $0.51^{\mathrm{ab}}$ & $0.12^{\mathrm{b}}$ & $57.8^{\mathrm{a}}$ & $-35.8^{\mathrm{a}}$ & $-25.1^{\mathrm{a}}$ & $63.8^{\mathrm{a}}$ & $-10.6^{\mathrm{bc}}$ & $41.7^{\mathrm{a}}$ \\
\hline 75 & MD & $4.2^{\mathrm{b}}$ & $0.06^{\mathrm{a}}$ & $0.04^{\mathrm{a}}$ & $0.44^{\mathrm{cd}}$ & $0.47^{\mathrm{abc}}$ & $0.14^{\mathrm{ab}}$ & $57.2^{\mathrm{a}}$ & $-35.1^{\mathrm{a}}$ & $-18.0^{\mathrm{a}}$ & $48.2^{\mathrm{bc}}$ & $-2.2^{\mathrm{abc}}$ & $28.8^{\mathrm{ab}}$ \\
\hline 75 & HD & $7.5^{\mathrm{a}}$ & $0.06^{\mathrm{a}}$ & $0.04^{\mathrm{a}}$ & $0.50^{\mathrm{bcd}}$ & $0.43^{\mathrm{cd}}$ & $0.16^{\mathrm{ab}}$ & $26.8^{\mathrm{b}}$ & $-21.8^{\mathrm{a}}$ & $-17.4^{\mathrm{a}}$ & $41.5^{\mathrm{bc}}$ & $5.1^{\mathrm{a}}$ & $22.4^{\mathrm{ab}}$ \\
\hline
\end{tabular}

Influence of swath density on mineral content of corn stover. Data are pooled over rainfall amount

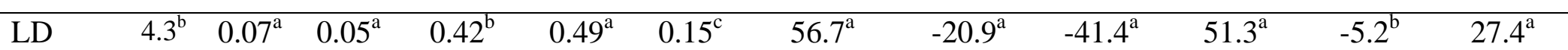




\begin{tabular}{|c|c|c|c|c|c|c|c|c|c|c|c|c|}
\hline MD & $4.0^{\mathrm{b}}$ & $0.06^{\mathrm{a}}$ & $0.05^{\mathrm{a}}$ & $0.61^{\mathrm{a}}$ & $0.43^{b}$ & $0.17^{\mathrm{b}}$ & $59.1^{\mathrm{a}}$ & $-24.5^{\mathrm{a}}$ & $-39.1^{\mathrm{a}}$ & $29.4^{\mathrm{b}}$ & $7.1^{\mathrm{a}}$ & $19.5^{b}$ \\
\hline HD & $8.2^{\mathrm{a}}$ & $0.06^{\mathrm{a}}$ & $0.05^{\mathrm{a}}$ & $0.62^{\mathrm{a}}$ & $0.42^{\mathrm{b}}$ & $0.18^{\mathrm{a}}$ & $19.0^{\mathrm{b}}$ & $-10.3^{a}$ & $-39.3^{\mathrm{a}}$ & $28.2^{\mathrm{b}}$ & $9.1^{\mathrm{a}}$ & $14.2^{\mathrm{C}}$ \\
\hline
\end{tabular}

Influence of rainfall amount on mineral content of corn stover. Data are pooled over swath density

\begin{tabular}{|c|c|c|c|c|c|c|c|c|c|c|c|c|}
\hline 8 & $5.8^{\mathrm{a}}$ & $0.06^{\mathrm{a}}$ & $0.05^{\mathrm{ab}}$ & $0.72^{\mathrm{a}}$ & $0.41^{b}$ & $0.19^{\mathrm{a}}$ & $41.1^{\mathrm{a}}$ & $-6.0^{\mathrm{a}}$ & $-40.8^{\mathrm{ab}}$ & $18.6^{\mathrm{C}}$ & $11.2^{\mathrm{a}}$ & $7.3^{\mathrm{a}}$ \\
\hline 25 & $5.2^{\mathrm{a}}$ & $0.06^{\mathrm{a}}$ & $0.05^{\mathrm{a}}$ & $0.60^{\mathrm{ab}}$ & $0.43^{\mathrm{b}}$ & $0.15^{\mathrm{a}}$ & $48.5^{\mathrm{a}}$ & $-20.1^{\mathrm{ab}}$ & $-42.6^{\mathrm{ab}}$ & $30.5^{\mathrm{bc}}$ & $9.4^{\mathrm{a}}$ & $26.8^{\mathrm{a}}$ \\
\hline 50 & $5.9^{\mathrm{a}}$ & $0.07^{\mathrm{a}}$ & $0.06^{\mathrm{a}}$ & $0.48^{\mathrm{bc}}$ & $0.48^{\mathrm{a}}$ & $0.17^{\mathrm{a}}$ & $42.8^{\mathrm{a}}$ & $-17.2^{\mathrm{ab}}$ & $-56.3^{b}$ & $45.0^{\mathrm{ab}}$ & $-3.3^{a}$ & $16.5^{\mathrm{a}}$ \\
\hline 75 & $5.3^{\mathrm{a}}$ & $0.06^{\mathrm{a}}$ & $0.05^{\mathrm{b}}$ & $0.42^{\mathrm{C}}$ & $0.47^{\mathrm{a}}$ & $0.14^{\mathrm{a}}$ & $47.3^{\mathrm{a}}$ & $-30.9^{b}$ & $-20.2^{\mathrm{a}}$ & $51.2^{\mathrm{a}}$ & $-2.6^{\mathrm{a}}$ & $31.0^{\mathrm{a}}$ \\
\hline
\end{tabular}

${ }^{\mathrm{Z}}$ Means within columns followed by different letters are significantly different at the 95\% confidence level. LD, MD, and HD is defined as low density, medium density, and high density, respectively. $* \%$ change is calculated by formulae, $\%$ Change $=$ $\frac{C_{i} \times D M_{i}-C_{f} \times D M_{f}}{C_{i} \times D M_{i}} \times 100$, where, $C$ and DM are the concentration and dry matter of the constituent being analysed, and subscriptsi and $f$ are the initial and final values 
270 Similarly, $\mathrm{K}^{+}$and $\mathrm{Mg}^{2+}$ ions, constituted about 5.3 to $7.3 \%$ and 1.0 to $1.9 \%$ of the dry weight of 271 water extractives from switchgrass, respectively (Chen at al., (2010). Chen at al. (2007) reported

272 that $\mathrm{Ca}^{+2}$ was the other major cation lost during extraction and was 1.2 to $1.7 \%$ of the dry weight 273 of water extractives. However, in the present study, significant increases of 5.2\% in LD swaths

274 and 3.3 and 2.6\% increases at rainfall amounts of 50 and $75 \mathrm{~mm}$ were observed in CS. These

275 increases might have come from the supply water used to simulate rainfall during the 276 experiments. Minerals such as $\mathrm{Mg}\left(1.5 \mathrm{mg} 100 \mathrm{~g}^{-1}\right)$, Ca (3.9 mg100g $\left.{ }^{-1}\right)$, Na $\left(6.8 \mathrm{mg} 100 \mathrm{~g}^{-1}\right), \mathrm{Cu}$

$277\left(0.008 \mathrm{mg}_{100 \mathrm{~g}^{-1}}\right), \mathrm{K}\left(0.5 \mathrm{mg} 100 \mathrm{~g}^{-1}\right)$ were reported in the Midwest water supply (Pehrsson, 278 Patterson, \& Perry, 2008). Small changes in S, P, and other micronutrients (B, Zn, Mn, Cu, Fe, $279 \mathrm{Na}$ ) were observed but no significant effect of rainfall amount or swath density was observed 280 (results presented as supplementary material in Tables A \& B).

$281 \quad 3.4 .2$ Ash

282 In switchgrass, rainfall decreased the ash content by 4.2 to $16.7 \%$ but the treatments were not 283 statistically different. LD swaths showed the maximum decrease of $13 \%$ as being more exposed 284 to rainfall but, it was also not significantly different than a reduction of $9.9 \%$ and $11.1 \%$ 285 observed in MD and HD swaths, respectively.

286 Being highly conditioned, the effect of rainfall was more pronounced in CS and ash content 287 decreased by $11.3 \%$ to $62.1 \%$ (Tables 3). Ash content of $4.3 \%$ was left in LD swaths compared 288 to $8.2 \%$ in HD swaths and were significantly different from each other. Ash content above 5\% is 289 not desirable in biomass for thermochemical processes (Tanger, Field, Jahn, DeFoort, \& Leach, 290 2013). Harvesting techniques such as single pass harvest is encouraged to keep the ash content 291 low. Ash and mineral content in biomass also negatively affect the thermochemical conversion 292 equipment. The elements $\mathrm{Na}, \mathrm{K}, \mathrm{Mg}, \mathrm{Ca}, \mathrm{Cl}, \mathrm{S}$ and $\mathrm{Si}$ produce problems such as slag formation 
293 (a liquid phase formed at elevated temperatures) and deposits during thermochemical processes.

294 Although silica in the plant tissue may be low, contamination with soil during the harvesting 295 process increases the silica content and thus leads to operational difficulties. High mineral 296 content in biomass also decreases oil yield and increases the production of char and gas products 297 during pyrolysis (Tanger, Field, Jahn, DeFoort, \& Leach, 2013).

\section{3.5. Change in fibre components}

$299 \quad 3.5 .1$ Plant cell wall

300

301

302

303

304

305

306

307

308

309

310

311

312

313

314

315
Plant cell wall (NDF) or fibre portions are insoluble in boiling water,so little to no change is expected after rainfall (Fonnesbeck, Hernandez, Kaykay, \& Saiady, 1986). Most of the changes are due to leaching of the soluble portions which indirectly increase the fibrecontent even though there is no actual change in fibre. Averaged over densities, plant cell wall content varied from 71.4 to $72.6 \%$ (Table 5) in the rain treated switchgrass and 74.3 to $74.7 \%$ (Table 6 ) in CS which showed that rainfall had no significant effect on plant cell wall content.

\subsubsection{Lignin}

In switchgrass, an increase of 6.2\% was observed at the higher rainfall amount of $75 \mathrm{~mm}$, and it decreased at other rainfall amounts. A significant effect of swath density was also observed but the differences were small with little practical significance. However, swath density significantly affected the lignin content in CS after rainfall. Lignin increased by $13.8 \%$ and $21.3 \%$ in LD and MD swaths compared to 3.2\% in HD swaths. For alfalfa,Fonnesbeck et al (1986) reported an increase of $8.5 \%$ and $14.3 \%$ from 5 and $20 \mathrm{~mm}$ of rainfall, respectively. An increase of 4.3 to 17.6\% was also reported by Collins (1983) from red clover treated with 25 to $62 \mathrm{~mm}$ of rainfall. A greater increase in lignin content in LD and MD swaths indicates that more soluble components were lost from LD and MD swaths when compared to HD swaths. The impact of 
316 lignin on fuel conversion is different for biochemical and thermochemical conversion

317 technologies. In the biochemical process, minimising the lignin content increases hydrolysis and

318 fermentation yields (Miles et al., 1996).

$319 \quad 3.5 .3$ Cellulose

320 Averaged over swath densities, cellulose varied from 41.7 to $42.5 \%$ in rainfall treated CS

321 samples. No significant difference in rainfall amount or swath densities was observed. Changes

322 were small and were not identified with any trend. A change of 3.5 to $6.6 \%$ (CS) and 0.8 to $3.6 \%$

323 (switchgrass) was observed from initial values which were consistent with other studies (Rotz,

324 1995). Fonnesbeck et al. (1986) reported a change of 5.2\% to $12.9 \%$ in cellulose content after 5

325 and $20 \mathrm{~mm}$ of rainfall from alfalfa.

326 3.5.4 Hemicellulose

327 Hemicellulose decreased by $4.1 \%$ to $7.6 \%$ (CS) and 0.6 to $11.3 \%$ (switchgrass) in water

328 treatment samples but no consistent trend was noted. A decrease of $7.4 \%$ hemicellulose content

329 was also observed in square switchgrass bales stored outside without any protection for 6 months

330 (Fonnesbeck, Hernandez, Kaykay, \& Saiady, 1986). It was found that under adverse conditions,

331 hemicellulose content is more severely affected than the cellulose content. Grohmann et al.

332 (1981) and Thammasouk, Tandjo, and Penner, (1997) reported that the rate of cleavage of $\beta$ -

333 xylans (major components of hemicellulose) is 5 times higher than $\beta$-glucans (a major

334 component of cellulose). However, in the present study, the decrease in hemicellulose content

335 was small and is of little practical significance. 
Table 5. Final extractives and fibre content left in switchgrass after the rainfall treatment and percent change in composition compared to initial values

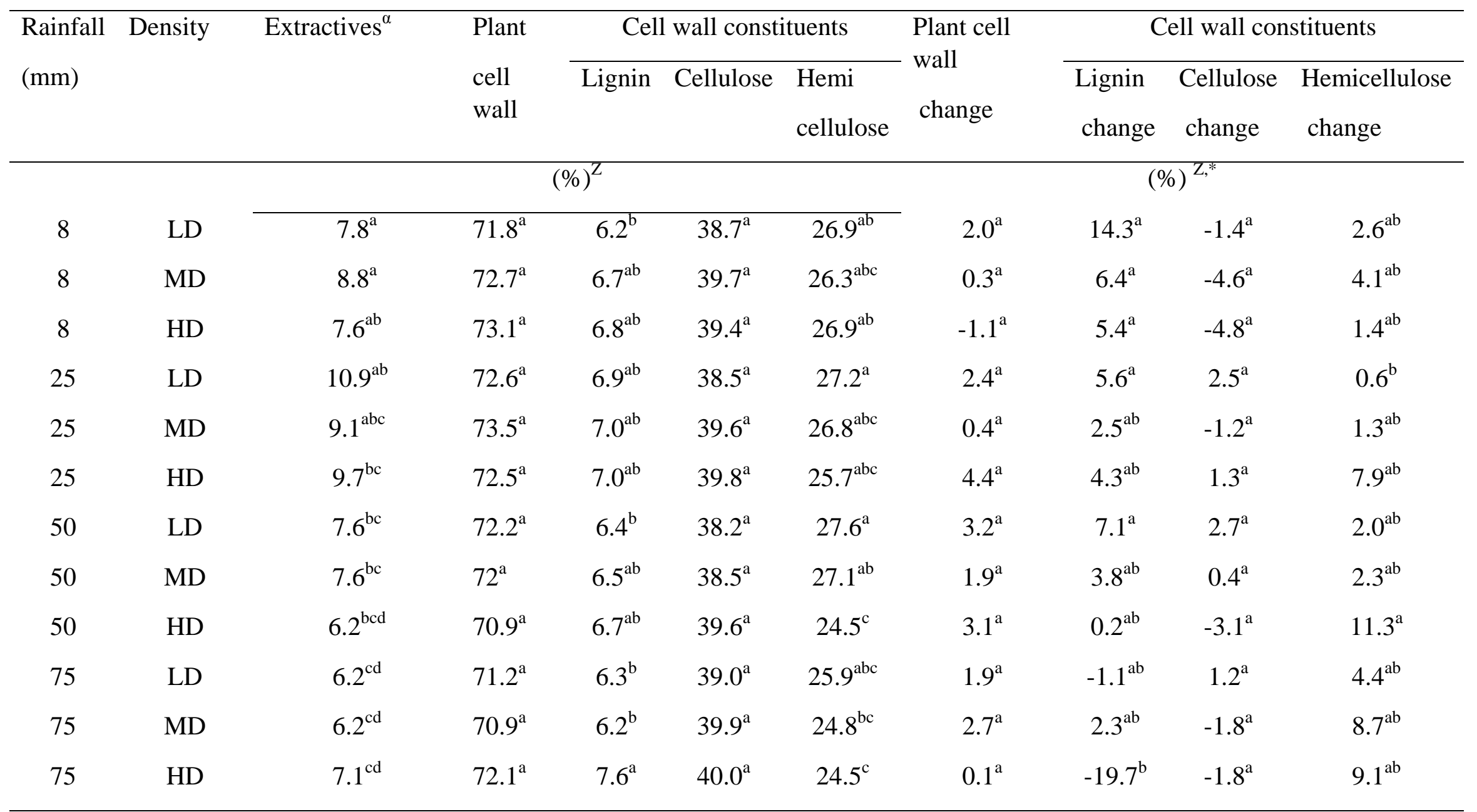

Influence of swath density on the changein extractives, ash and fiber content of switchgrass. Data are pooled over rainfall amount

LD

$8.2^{\mathrm{a}}$

$\begin{array}{lll}71.9^{\mathrm{a}} & 6.5^{\mathrm{b}} \quad 38.6^{\mathrm{a}}\end{array}$

$26.9^{\mathrm{a}}$

$2.4^{\mathrm{a}}$

$\begin{array}{ll}6.5^{\mathrm{a}} & 1.0^{\mathrm{a}}\end{array}$

$2.4^{\mathrm{b}}$ 


\begin{tabular}{|c|c|c|c|c|c|c|c|c|c|}
\hline MD & $7.9^{\mathrm{a}}$ & $72.3^{\mathrm{a}}$ & $6.6^{\mathrm{ab}}$ & $39.4^{\mathrm{a}}$ & $26.3^{\mathrm{ab}}$ & $1.3^{\mathrm{a}}$ & $3.8^{\mathrm{ab}}$ & $-1.8^{b}$ & $4.1^{\mathrm{ab}}$ \\
\hline HD & $7.6^{\mathrm{a}}$ & $72.2^{\mathrm{a}}$ & $7.0^{\mathrm{a}}$ & $39.7^{\mathrm{a}}$ & $25.4^{\mathrm{b}}$ & $1.6^{\mathrm{a}}$ & $-2.5^{\mathrm{b}}$ & $-2.4^{\mathrm{b}}$ & $7.4^{\mathrm{a}}$ \\
\hline
\end{tabular}

\begin{tabular}{|c|c|c|c|c|c|c|c|c|c|}
\hline 8 & $8.1^{b}$ & $72.6^{\mathrm{a}}$ & $6.6^{\mathrm{a}}$ & $39.3^{\mathrm{a}}$ & $26.7^{\mathrm{a}}$ & $0.4^{\mathrm{a}}$ & $8.7^{\mathrm{a}}$ & $-3.6^{\mathrm{a}}$ & $2.7^{\mathrm{a}}$ \\
\hline 25 & $9.9^{\mathrm{a}}$ & $72.9^{\mathrm{a}}$ & $7.0^{\mathrm{a}}$ & $39.3^{\mathrm{a}}$ & $26.6^{\mathrm{a}}$ & $2.4^{\mathrm{a}}$ & $4.1^{\mathrm{a}}$ & $0.8^{\mathrm{a}}$ & $3.3^{\mathrm{a}}$ \\
\hline 50 & $7.2^{\mathrm{bc}}$ & $71.7^{\mathrm{a}}$ & $6.5^{\mathrm{a}}$ & $38.8^{\mathrm{a}}$ & $26.4^{\mathrm{ab}}$ & $2.8^{\mathrm{a}}$ & $3.7^{\mathrm{a}}$ & $0.0^{\mathrm{a}}$ & $5.2^{\mathrm{a}}$ \\
\hline 75 & $6.5^{c}$ & $71.4^{\mathrm{a}}$ & $6.7^{\mathrm{a}}$ & $39.7^{\mathrm{a}}$ & $25.1^{b}$ & $1.5^{\mathrm{a}}$ & $-6.2^{\mathrm{a}}$ & $-0.8^{\mathrm{a}}$ & $7.4^{\mathrm{a}}$ \\
\hline
\end{tabular}

\footnotetext{
${ }^{\mathrm{Z}}$ Means within columns followed by different letters are significantly different at the 95\% confidence level. ${ }^{\alpha}$ Extractive change presented in Table 2. LD, MD, and HD is defined as low density, medium density, and high density, respectively. *\% change is calculated by formulae, \% Change $=\frac{C_{i} \times D M_{i}-C_{f} \times D M_{f}}{C_{i} \times D M_{i}} \times 100$, where, C and DM are the concentration and dry matter of the constituent being analysed, and subscriptsi and $f$ are the initial and final values
} 
Table 6. Final extractives and fibre content left in corn stover after the rainfall treatment and percent change in composition compared to initial values

\begin{tabular}{|c|c|c|c|c|c|c|c|c|c|c|c|c|}
\hline \multirow{2}{*}{$\begin{array}{l}\text { Rainfall } \\
(\mathrm{mm})\end{array}$} & \multirow[t]{2}{*}{ Density } & Extractives $^{\alpha}$ & $\begin{array}{l}\text { Plant } \\
\text { cell } \\
\text { wall }\end{array}$ & \multicolumn{4}{|c|}{ Cell wall constituents } & $\begin{array}{l}\text { Plant } \\
\text { cell } \\
\text { wall } \\
\text { change }\end{array}$ & \multicolumn{4}{|c|}{ Cell wall constituents } \\
\hline & & \multicolumn{7}{|c|}{$(\%)^{\mathrm{Z}}$} & \multicolumn{3}{|c|}{$(\%)^{Z, *}$} & $\begin{array}{l}\text { Hemicellulose } \\
\text { change }\end{array}$ \\
\hline 8 & LD & $7.8^{\mathrm{a}}$ & $71.8^{\mathrm{a}}$ & & $6.2^{b}$ & $38.7^{\mathrm{a}}$ & 26. & & $2.0^{\mathrm{a}}$ & $14.3^{\mathrm{a}}$ & $-1.4^{\mathrm{a}}$ & $2.6^{\mathrm{ab}}$ \\
\hline 8 & HD & $7.6^{\mathrm{ab}}$ & $73.1^{\mathrm{a}}$ & & $5.8^{\mathrm{ab}}$ & $39.4^{\mathrm{a}}$ & 26. & & $-1.1^{\mathrm{a}}$ & $5.4^{\mathrm{a}}$ & $-4.8^{\mathrm{a}}$ & $1.4^{\mathrm{ab}}$ \\
\hline 25 & LD & $10.9^{\mathrm{ab}}$ & $72.6^{\mathrm{a}}$ & & $5.9^{\mathrm{ab}}$ & $38.5^{\mathrm{a}}$ & 27. & & $2.4^{\mathrm{a}}$ & $5.6^{\mathrm{a}}$ & $2.5^{\mathrm{a}}$ & $0.6^{\mathrm{b}}$ \\
\hline 25 & MD & $9.1^{\mathrm{abc}}$ & $73.5^{\mathrm{a}}$ & & $7.0^{\mathrm{ab}}$ & $39.6^{\mathrm{a}}$ & 26.8 & & $0.4^{\mathrm{a}}$ & $2.5^{\mathrm{ab}}$ & $-1.2^{\mathrm{a}}$ & $1.3^{\mathrm{ab}}$ \\
\hline 50 & HD & $6.2^{\mathrm{bcd}}$ & $70.9^{\mathrm{a}}$ & & $5.7^{\mathrm{ab}}$ & $39.6^{\mathrm{a}}$ & 24. & & $3.1^{\mathrm{a}}$ & $0.2^{\mathrm{ab}}$ & $-3.1^{\mathrm{a}}$ & $11.3^{\mathrm{a}}$ \\
\hline 75 & LD & $6.2^{\mathrm{cd}}$ & $71.2^{\mathrm{a}}$ & & $6.3^{b}$ & $39.0^{\mathrm{a}}$ & 25.9 & $9^{\mathrm{abc}}$ & $1.9^{\mathrm{a}}$ & $-1.1^{\mathrm{ab}}$ & $1.2^{\mathrm{a}}$ & $4.4^{\mathrm{ab}}$ \\
\hline 75 & MD & $6.2^{\mathrm{cd}}$ & $70.9^{\mathrm{a}}$ & & $6.2^{\mathrm{b}}$ & $39.9^{\mathrm{a}}$ & 24.8 & & $2.7^{\mathrm{a}}$ & $2.3^{\mathrm{ab}}$ & $-1.8^{\mathrm{a}}$ & $8.7^{\mathrm{ab}}$ \\
\hline 75 & HD & $7.1^{\mathrm{cd}}$ & $72.1^{\mathrm{a}}$ & & $7.6^{\mathrm{a}}$ & $40.0^{\mathrm{a}}$ & 24. & & $0.1^{\mathrm{a}}$ & $-19.7^{b}$ & $-1.8^{\mathrm{a}}$ & $9.1^{\mathrm{ab}}$ \\
\hline
\end{tabular}

Influence of swath density on change in in extractives, ash and fibre content of corn stover. Data are pooled over rainfall amount

LD

$6.8^{\mathrm{a}}$

$74.0^{\mathrm{b}}$

$6.0^{\mathrm{a}}$

$41.6^{\mathrm{a}}$

$26.4^{\mathrm{a}}$

$5.7^{\mathrm{a}}$

$-13.8^{\mathrm{b}} \quad 7.4^{\mathrm{a}}$

$6.6^{\mathrm{a}}$ 


$\begin{array}{llllllllll}\text { MD } & 6.4^{\mathrm{a}} & 75.2^{\mathrm{a}} & 6.2^{\mathrm{a}} & 42.3^{\mathrm{a}} & 26.6^{\mathrm{a}} & 3.4^{\mathrm{b}} & -21.3^{\mathrm{b}} & 4.9^{\mathrm{ab}} & 5.1^{\mathrm{a}} \\ \mathrm{HD} & 7.1^{\mathrm{a}} & 74.1^{\mathrm{ab}} & 5.3^{\mathrm{b}} & 42.6^{\mathrm{a}} & 26.2^{\mathrm{a}} & 4.2^{\mathrm{ab}} & -3.2^{\mathrm{a}} & 3.9^{\mathrm{b}} & 5.7^{\mathrm{a}}\end{array}$

Influence rainfall amount on change in in extractives, ash and fibre content of corn stover. Data are pooled over swath density

\begin{tabular}{|c|c|c|c|c|c|c|c|c|c|}
\hline 8 & $8.3^{\mathrm{a}}$ & $74.3^{\mathrm{a}}$ & $5.6^{\mathrm{a}}$ & $42.3^{\mathrm{a}}$ & $26.3^{\mathrm{a}}$ & $4.6^{\mathrm{a}}$ & $-9.6^{\mathrm{a}}$ & $5.0^{\mathrm{a}}$ & $6.2^{\mathrm{a}}$ \\
\hline 50 & $6.1^{\mathrm{b}}$ & $74.7^{\mathrm{a}}$ & $6.2^{\mathrm{a}}$ & $41.7^{\mathrm{a}}$ & $26.8^{\mathrm{a}}$ & $3.9^{\mathrm{a}}$ & $-20.0^{a}$ & $6.4^{\mathrm{a}}$ & $4.1^{\mathrm{a}}$ \\
\hline 75 & $6.2^{\mathrm{b}}$ & $74.4^{\mathrm{a}}$ & $5.7^{\mathrm{a}}$ & $42.5^{\mathrm{a}}$ & $26.2^{\mathrm{a}}$ & $3.3^{\mathrm{a}}$ & $-11.6^{\mathrm{a}}$ & $3.5^{\mathrm{a}}$ & $5.3^{\mathrm{a}}$ \\
\hline
\end{tabular}

${ }^{\mathrm{Z}}$ Means within columns followed by different letters are significantly different at the 95\% confidence level. ${ }^{\alpha}$ Extractive change presented in Table 2. LD, MD, and HD is defined as low density, medium density, and high density, respectively. ${ }^{*} \%$ change is calculated by formulae, \% Change $=\frac{C_{i} \times D M_{i}-C_{f} \times D M_{f}}{C_{i} \times D M_{i}} \times 100$, where, C and DM are the concentration and dry matter of the constituent being analysed, and subscriptsi and $f$ are the initial and final values 
336 Dry matter losses due to rainfall directly influence the economics of biofuel production and

337 should be considered in determining the biomass supply cost to biorefineries. The dry matter lost

338 during rainfall must be supplemented by harvesting more biomass to meet the demand of

339 biorefineries. Rainfall losses can be minimised by placing the crop in narrow windrows so that

340 the underlying layers can be protected by the top layers. However, to minimise respiration loss

341 after a rainfall event, the cropmust be dried in wide swaths to intercept maximum solar radiation.

342 But, these operations will increase the overall cost of harvesting and supplying the biomass to

343 biorefineries. The cost advantage achieved by saving the dry matter during a rainfall event

344 should be compared with the cost of subsequent field operations applied to minimise the loss.

\section{$345 \quad 4.0$ Conclusion}

346 This study demonstrated the effect of rainfall amount and swath density on dry matter loss and

347 compositional changes during the field drying of switchgrass and CS. Significant changes in the

348 soluble portion were observed with more losses from LD swaths compared to MD, and HD

349 swaths. Dry matter losses up to 6\% in switchgrass and 9\% in CS were observed after rainfall

350 treatments. Rainfall removed both desirable (water soluble carbohydrates) and undesirable

351 (minerals, ash) components from the biomass. Water soluble carbohydrates can be easily

352 fermented to ethanol by the biochemical conversion process and therefore, should be protected

353 during the drying period. Small changes in the fibre portions were observed which were

354 primarily due to adecreasein the soluble portion of biomass rather than actual changes in the

355 fibre. Minerals K and Mg, which are water soluble, decreased after rainfall and both rainfall

356 amount and swath density significantly affected the final concentration.

\section{Acknowledgements}


We acknowledge the financial support from the CenUSA Bioenergy project funded by

Agriculture and Food Research Initiative Competitive Grant No. 2011-68005-30411 from the

USDA National Institute of Food and Agriculture. We also would like to acknowledge the

guidance and assistance offered by Dr. Matthew Helmers and Carl H. Pederson for the rainfall

simulator used in the study.

\section{References}

ASAE. (2003). ASAE Standard S358.2 Moisture measurement-forages. St. Joseph, MI, USA: American Society of Agricultural and Biological Engineers.

Chen, S.-F., Mowery, R. A., Scarlata, C. J., \& Chambliss, C. K. (2007). Compositional analysis of watersoluble materials in corn stover. Journal of Agricultural and Food Chemistry, 55, 5912-5918.

Chen, S.-F., Mowery, R. A., Sevcik, R. S., Scarlata, C. J., \& Chambliss, C. K. (2010). Compositional analysis of water-soluble materials in switchgrass. Journal of Agricultural and Food Chemistry, 58, 32513258.

Collins, M. (1983). Wetting and maturity effects on the yield and quality of legume hay. Agronomy Journal, 75, 523-527.

Fonnesbeck, P. V., Hernandez, M. M. G. D., Kaykay, J. M., \& Saiady, M. Y. (1986). Estimating yield and nutrient losses due to rainfall on field-drying alfalfa hay. Animal Feed Science and Technology, 16(1), 7-15.

Grohmann, K., Torget, R., \& Himmel, M. (1981). Optimization of dilute acid pretreatment of biomass. Biotechnology and Bioengineering Symposium, 15, 59-80.

Jones, J. B., \& Case, V. W. (1990). Sampling, handling, and analyzing plant tissue samples. In R. L. Westerman (Ed.), Soil Testing and Plant Analysis (pp. 389-427). Madison, WI: Soil Science Society of America.

Jung, H.-J. G., \& Lamb, J. F. S. (2004). Prediction of cell wall polysaccharide and lignin concentrations of alfalfa stems from detergent fiber analysis. Biomass and Bioenergy, 27, 365-373.

Kallis, K. X., Susini, G. A. P., \& Oakey, J. E. (2013). A comparison between Miscanthus and bioethanol waste pellets and their performance in a downdraft gasifier. Applied Energy, 101, 333-340.

Khanchi, A., Jones, C. L., Sharma, B., Huhnke, R. L., Weckler, P., \& Maness, N. O. (2013). An empirical model to predict infield thin layer drying rate of cut switchgrass. Biomass and Bioenergy, 58, 128-135.

Kormos, J., \& Chestnutt, D. M. B. (1968). Measurement of dry matter losses in grass during the wilting period - (2) The effects of rain, mechanical treatment, maturity of grass and some other factors. Record of the MInistry of Agriculture, 17, 59-65.

McGechan, M. B. (1989). A review of losses arising during conservation of grass forage: Part 1, field losses. Journal of Agricultural Engineering Research, 44, 1-21.

Mertens, D. R. (1992). Critical conditions in determining detergent fibers. Paper presented at the Proc. NFTA Forage Analysis Workshop, Denver, CO.

Miles, T. R., Miles, T. R. J., Baxter, L. L., Bryers, R. W., Jenkins, B. M., \& Oden, L. L. (1996). Strategic Benefits of Biomass and Wasteful fuelsBoiler deposits from firing biomass fuels. Biomass and Bioenergy, 10, 125-138. 
Norton, L. D., \& Savabi, R. (2010). Evolution of a Linear Variable Intensity Rainfall Simulator for Surface Hydrology and Erosion Studies. Applied Engineering in Agriculture, 26, 239-245.

Pehrsson, P., Patterson, K., \& Perry, C. (2008). The mineral content of US drinking and municipal water. USDA, Agricultural Research Service, Human Nutrition Research Center, Nutrient Data Laboratory, Beltsville, MD. . Retrieved from http://www.ars.usda.gov/SP2UserFiles/Place/80400525/Articles/NDBC32_WaterMin.pdf.

Rotz, C. A. (1995). Loss models for forage harvest. Transactions of ASAE, 38, 1621-1631.

Rucker, G., \& Knabe, O. (1977). Non-mechanical field losses in wilting grasses as influenced by different factors. Paper presented at the Proceedings 13th International Grassland Congress, Leipzig.

SAS Institute. (2015) (Version SAS 9.4 TS Level 2 MO) [X64_ESRV Platform]. Cary, NC, USA.

Sluiter, A., Hames, B., Ruiz, R., Scarlata, C., Sluiter, J., \& Templeton, D. (2008). Determination of ash in biomass Laboratory analytical procedures. from National Renewable Energy Laboratory

http://www.nrel.gov/biomass/pdfs/42622.pdf

Sluiter, A., Ruiz, R., Scarlata, J., \& Templeton, D. (2008). Determination of extractives in biomass. Laboratory analytical procedure (LAP). from National Renewable Energy Laboratory http://www.nrel.gov/docs/gen/fy08/42619.pdf

Sultana, A., \& Kumar, A. (2012). Ranking of biomass pellets by integration of economic, environmental and technical factors. Biomass and Bioenergy, 39, 344-355.

Tanger, P., Field, J. L., Jahn, C. E., DeFoort, M. W., \& Leach, J. E. (2013). Biomass for thermochemical conversion: targets and challenges. Frontiers in Plant Science, 4, 218.

Thammasouk, K., Tandjo, D., \& Penner, M. H. (1997). Influence of Extractives on the Analysis of Herbaceous Biomass. Journal of Agricultural and Food Chemistry, 45, 437-443.

Valtere, S., Kirsanovs, V., \& Zandeckis, A. (2015). International Scientific Conference "Environmental and Climate Technologies, CONECT 2014Investigation of Biomass Gasification Process with Torrefaction Using Equilibrium Model. Energy Procedia, 72, 329-336.

Van Soest, P. J., Robertson, J. B., \& Lewis, B. A. (1991). Methods for Dietary Fiber, Neutral Detergent Fiber, and Nonstarch Polysaccharides in Relation to Animal Nutrition. Journal of Dairy Science, 74(10), 3583-3597.

Wood, J. G. M., \& Parker, J. (1971). Respiration during the drying of hay. Journal of Agriciltural Engineering Research, 16(3), 179-191. 


\section{Appendix A}

Table A. Final micronutrients concentration left in switchgrass after the rainfall treatment and percent change in concentration compared to initial values

\begin{tabular}{|c|c|c|c|c|c|c|c|c|c|c|c|c|c|}
\hline $\begin{array}{l}\text { Rainfall } \\
\text { (mm) }\end{array}$ & Density & B & $\mathrm{Zn}$ & $\mathrm{Mn}$ & $\mathrm{Cu}$ & $\mathrm{Fe}$ & $\mathrm{Na}$ & $\begin{array}{l}\mathrm{B} \\
\text { change }\end{array}$ & $\begin{array}{l}\mathrm{Zn} \\
\text { change }\end{array}$ & $\begin{array}{l}\text { Mn } \\
\text { change }\end{array}$ & $\begin{array}{l}\mathrm{Cu} \\
\text { change }\end{array}$ & $\begin{array}{l}\mathrm{Fe} \\
\text { change }\end{array}$ & $\begin{array}{l}\mathrm{Na} \\
\text { change }\end{array}$ \\
\hline & & \multicolumn{6}{|c|}{$\mathrm{ppm}^{\mathrm{Z}}$} & \multicolumn{6}{|c|}{$\%{ }^{*, Z}$} \\
\hline 8 & LD & $5.7^{\mathrm{ab}}$ & $9.0^{\mathrm{a}}$ & $12.6^{\mathrm{a}}$ & $2.8^{\mathrm{a}}$ & $98.9^{\mathrm{ab}}$ & $475.0^{\mathrm{a}}$ & $-48.0^{\mathrm{ab}}$ & $1.7^{\mathrm{ab}}$ & $-2.8^{a b c}$ & $14.0^{\mathrm{a}}$ & $8.3^{\mathrm{a}}$ & $-86.7^{a}$ \\
\hline 8 & $\mathrm{MD}$ & $4.6^{\mathrm{b}}$ & $8.7^{\mathrm{a}}$ & $10.5^{\mathrm{a}}$ & $2.9^{\mathrm{a}}$ & $86.7^{\mathrm{b}}$ & $381.0^{\mathrm{a}}$ & $-10.8^{\mathrm{ab}}$ & $1.8^{\mathrm{ab}}$ & $11.8^{\mathrm{abc}}$ & $8.2^{\mathrm{a}}$ & $18.4^{\mathrm{a}}$ & $-73.4^{\mathrm{a}}$ \\
\hline 8 & HD & $5.5^{\mathrm{ab}}$ & $11.8^{\mathrm{ab}}$ & $12.4^{\mathrm{ab}}$ & $3.2^{\mathrm{ab}}$ & $106.0^{\mathrm{ab}}$ & $261.7^{\mathrm{a}}$ & $-45.6^{a b}$ & $-27.7^{b c}$ & $-1.1^{a b c}$ & $7.5^{\mathrm{a}}$ & $-6.4^{\mathrm{a}}$ & $-3.7^{\mathrm{a}}$ \\
\hline 25 & LD & $5.7^{\mathrm{ab}}$ & $9.7^{\mathrm{ab}}$ & $10.1^{\mathrm{ab}}$ & $3.1^{\mathrm{ab}}$ & $92.5^{\mathrm{ab}}$ & $305.0^{\mathrm{a}}$ & $-36.6^{\mathrm{ab}}$ & $11.4^{\mathrm{ab}}$ & $32.9^{\mathrm{abc}}$ & $5.4^{\mathrm{a}}$ & $21.5^{\mathrm{a}}$ & $-7.7^{\mathrm{a}}$ \\
\hline 25 & MD & $5.5^{\mathrm{ab}}$ & $8.4^{\mathrm{abc}}$ & $8.7^{\mathrm{abc}}$ & $2.7^{\mathrm{abc}}$ & $106.4^{\mathrm{ab}}$ & $282.0^{\mathrm{a}}$ & $-19.4^{\mathrm{ab}}$ & $22.6^{\mathrm{a}}$ & $39.2^{\mathrm{ab}}$ & $4.4^{\mathrm{a}}$ & $14.4^{\mathrm{a}}$ & $-3.5^{\mathrm{a}}$ \\
\hline 25 & $\mathrm{HD}$ & $5.8^{\mathrm{ab}}$ & $10.3^{\mathrm{abc}}$ & $8.0^{\mathrm{abc}}$ & $3.3^{\mathrm{abc}}$ & $90.7^{\mathrm{ab}}$ & $472.7^{\mathrm{a}}$ & $-21.4^{\mathrm{ab}}$ & $8.6^{\mathrm{ab}}$ & $46.6^{a}$ & $3.6^{\mathrm{a}}$ & $24.7^{\mathrm{a}}$ & $-53.5^{a}$ \\
\hline 50 & LD & $6.4^{\mathrm{ab}}$ & $10.7^{\mathrm{abc}}$ & $9.9^{\mathrm{abc}}$ & $3.1^{\mathrm{abc}}$ & $166.6^{\mathrm{a}}$ & $437.7^{\mathrm{a}}$ & $-12.0^{\mathrm{ab}}$ & $3.3^{\mathrm{ab}}$ & $34.7^{\mathrm{ab}}$ & $1.3^{\mathrm{ab}}$ & $0.3^{\mathrm{a}}$ & $-123.5^{a}$ \\
\hline 50 & $\mathrm{MD}$ & $5.4^{\mathrm{ab}}$ & $10.4^{\mathrm{abc}}$ & $10.6^{\mathrm{bc}}$ & $3.3^{\mathrm{abc}}$ & $119.0^{\mathrm{ab}}$ & $453.3^{\mathrm{a}}$ & $3.8^{\mathrm{ab}}$ & $4.7^{\mathrm{ab}}$ & $28.3^{\mathrm{abc}}$ & $-1.7^{\mathrm{abc}}$ & $27.0^{\mathrm{a}}$ & $-113.9^{a}$ \\
\hline 50 & $\mathrm{HD}$ & $6.2^{\mathrm{ab}}$ & $10.9^{\mathrm{abc}}$ & $10.3^{\mathrm{bc}}$ & $3.2^{\mathrm{abc}}$ & $123.9^{\mathrm{ab}}$ & $339.0^{\mathrm{a}}$ & $-13.7^{a b}$ & $0.2^{\mathrm{ab}}$ & $31.3^{\mathrm{abc}}$ & $-3.2^{\mathrm{abc}}$ & $23.7^{\mathrm{a}}$ & $-82.1^{a}$ \\
\hline 75 & LD & $12.0^{\mathrm{a}}$ & $14.8^{\mathrm{abc}}$ & $27.0^{\mathrm{bc}}$ & $4.4^{\mathrm{abc}}$ & $156.3^{\mathrm{ab}}$ & $373.7^{\mathrm{a}}$ & $-129.9^{b}$ & $-39.2^{c}$ & $-74.6^{c}$ & $-5.6^{a b c}$ & $-16.1^{a}$ & $-69.4^{a}$ \\
\hline 75 & MD & $4.3^{b}$ & $10.9^{\mathrm{abc}}$ & $10.1^{\mathrm{bc}}$ & $3.2^{\mathrm{abc}}$ & $123.0^{\mathrm{ab}}$ & $377.7^{\mathrm{a}}$ & $19.3^{a}$ & $-2.7^{a b c}$ & $33.7^{\mathrm{ab}}$ & $-39.0^{b c}$ & $4.1^{\mathrm{a}}$ & $-71.1^{\mathrm{a}}$ \\
\hline 75 & HD & $11.3^{\mathrm{ab}}$ & $13.5^{\mathrm{abc}}$ & $25.2^{\mathrm{bc}}$ & $4.3^{\mathrm{abc}}$ & $146.0^{\mathrm{ab}}$ & $341.7^{\mathrm{a}}$ & $-117.1^{a b}$ & $-26.3^{b c}$ & $-64.5^{b c}$ & $-43.4^{c}$ & $-10.1^{\mathrm{a}}$ & $-55.8^{\mathrm{a}}$ \\
\hline
\end{tabular}

Influence of swath density on micronutrient concentration of switchgrass. Data are pooled over rainfall amount

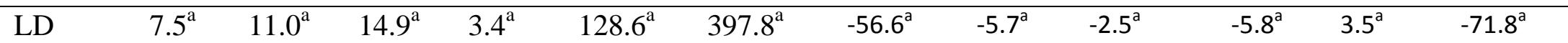




\begin{tabular}{|c|c|c|c|c|c|c|c|c|c|c|c|c|}
\hline $\mathrm{MD}$ & $4.9^{\mathrm{a}}$ & $9.6^{\mathrm{a}}$ & $10.0^{\mathrm{a}}$ & $3.0^{\mathrm{a}}$ & $116.6^{\mathrm{a}}$ & $373.5^{\mathrm{a}}$ & $-1.8^{\mathrm{a}}$ & $6.6^{\mathrm{a}}$ & $28.2^{\mathrm{a}}$ & $4.4^{\mathrm{a}}$ & $16.0^{\mathrm{a}}$ & $-65.5^{\circ}$ \\
\hline [D & $7.2^{\mathrm{a}}$ & $11.6^{\mathrm{a}}$ & $14.0^{\mathrm{a}}$ & $3.5^{\mathrm{a}}$ & $108.8^{\mathrm{a}}$ & $353.8^{\mathrm{a}}$ & $-49.5^{a}$ & $-11.3^{a}$ & $3.1^{\mathrm{a}}$ & $-10.7^{a}$ & $8.0^{\mathrm{a}}$ & $-48.8^{\circ}$ \\
\hline
\end{tabular}

Influence of rainfall amount on micronutrient concentration of switchgrass. Data are pooled over swath density

\begin{tabular}{|c|c|c|c|c|c|c|c|c|c|c|c|c|}
\hline 8 & $5.3^{\mathrm{a}}$ & $9.8^{b}$ & $11.9^{\mathrm{ab}}$ & $3.0^{b}$ & $97.2^{b}$ & $372.6^{\mathrm{a}}$ & $-34.8^{\mathrm{a}}$ & $-8.1^{\mathrm{ab}}$ & $2.6^{\mathrm{ab}}$ & $2.7^{\mathrm{a}}$ & $6.8^{\mathrm{ab}}$ & $-54.6^{\mathrm{ab}}$ \\
\hline 25 & $5.7^{\mathrm{a}}$ & $9.5^{\mathrm{b}}$ & $8.9^{b}$ & $3.0^{\mathrm{b}}$ & $96.5^{b}$ & $353.2^{\mathrm{a}}$ & $-25.8^{a}$ & $14.2^{\mathrm{a}}$ & $39.6^{a}$ & $5.6^{\mathrm{a}}$ & $20.2^{a}$ & $-21.6^{a}$ \\
\hline 50 & $6.0^{\mathrm{a}}$ & $10.6^{\mathrm{ab}}$ & $10.2^{\mathrm{b}}$ & $3.2^{\mathrm{ab}}$ & $136.5^{\mathrm{ab}}$ & $410.0^{\mathrm{a}}$ & $-7.3^{\mathrm{a}}$ & $2.7^{\mathrm{a}}$ & $31.4^{\mathrm{a}}$ & $4.1^{\mathrm{a}}$ & $17.0^{\mathrm{ab}}$ & $-106.5^{b}$ \\
\hline 75 & $9.2^{\mathrm{a}}$ & $13.0^{\mathrm{a}}$ & $20.8^{\mathrm{a}}$ & $4.0^{\mathrm{a}}$ & $141.8^{\mathrm{a}}$ & $364.3^{\mathrm{a}}$ & $-75.9^{a}$ & $-22.7^{b}$ & $-35.1^{b}$ & $-28.5^{b}$ & $-7.4^{b}$ & $-65.4^{\mathrm{ab}}$ \\
\hline
\end{tabular}

${ }^{\mathrm{Z}}$ Means within columns followed by different letters are significantly different at the 95\% confidence level. LD, MD, and HD is defined as low density, medium density and high density, respectively. $* \%$ change is calculated by formulae, $\% \mathrm{Change}=\frac{C_{i} \times D M_{i}-C_{f} \times D M_{f}}{C_{i} \times D M_{i}} \times 100$, where, $\mathrm{C}$ and DM are the concentration and dry matter of the constituent being analysed, and subscriptsi and $f$ are the initial and final values 


\section{Appendix B}

Table B. Final mineral content left in corn stover after the rainfall treatment and percent change in composition compared to initial values

\begin{tabular}{|c|c|c|c|c|c|c|c|c|c|c|c|c|c|}
\hline $\begin{array}{l}\text { Rainfall } \\
(\mathrm{mm})\end{array}$ & Density & B & $\mathrm{Zn}$ & $\mathrm{Mn}$ & $\mathrm{Cu}$ & $\mathrm{Fe}$ & $\mathrm{Na}$ & $\begin{array}{c}\text { B } \\
\text { change }\end{array}$ & $\begin{array}{c}\text { Zn } \\
\text { change }\end{array}$ & $\begin{array}{c}\text { Mn } \\
\text { change }\end{array}$ & $\begin{array}{c}\mathrm{Cu} \\
\text { change }\end{array}$ & $\begin{array}{c}\text { Fe } \\
\text { change }\end{array}$ & $\begin{array}{c}\mathrm{Na} \\
\text { change }\end{array}$ \\
\hline & & \multicolumn{6}{|c|}{$\mathrm{ppm}^{\mathrm{Z}}$} & \multicolumn{6}{|c|}{$\%{ }^{\mathrm{z}, *}$} \\
\hline 8 & LD & $7.2^{\mathrm{ab}}$ & $12.2^{\mathrm{b}}$ & $11.0^{\mathrm{a}}$ & $3.1^{\mathrm{a}}$ & $68.2^{\mathrm{a}}$ & $286.7^{\mathrm{ab}}$ & $-16.4^{\mathrm{a}}$ & $-18.0^{\mathrm{ab}}$ & $12.2^{\mathrm{a}}$ & $-1.7^{\mathrm{a}}$ & $-22.3^{\mathrm{ab}}$ & $-46.3^{\mathrm{ab}}$ \\
\hline 8 & MD & $6.2^{\mathrm{b}}$ & $11.8^{\mathrm{b}}$ & $11.3^{\mathrm{a}}$ & $3.2^{\mathrm{a}}$ & $46.9^{\mathrm{a}}$ & $249.7^{b}$ & $-1.7^{\mathrm{a}}$ & $-14.4^{\mathrm{a}}$ & $10.1^{\mathrm{a}}$ & $-5.9^{\mathrm{a}}$ & $15.6^{\mathrm{a}}$ & $-28.5^{a}$ \\
\hline 8 & HD & $6.0^{\mathrm{b}}$ & $14.4^{\mathrm{ab}}$ & $15.5^{\mathrm{a}}$ & $3.3^{\mathrm{a}}$ & $59.2^{\mathrm{a}}$ & $448.0^{\mathrm{ab}}$ & $0.1^{\mathrm{a}}$ & $-41.7^{\mathrm{ab}}$ & $-30.3^{\mathrm{a}}$ & $-8.8^{\mathrm{a}}$ & $-8.8^{\mathrm{ab}}$ & $-134.4^{\mathrm{ab}}$ \\
\hline 25 & LD & $7.0^{\mathrm{ab}}$ & $14.1^{\mathrm{b}}$ & $12.8^{\mathrm{a}}$ & $3.2^{\mathrm{a}}$ & $79.9^{\mathrm{a}}$ & $306.3^{\mathrm{ab}}$ & $-9.8^{\mathrm{a}}$ & $-31.9^{a b}$ & $12.6^{\mathrm{a}}$ & $-0.5^{\mathrm{a}}$ & $-38.0^{\mathrm{ab}}$ & $-51.7^{\mathrm{ab}}$ \\
\hline 25 & $\mathrm{MD}$ & $18.0^{\mathrm{a}}$ & $22.0^{\mathrm{a}}$ & $13.4^{\mathrm{a}}$ & $5.3^{\mathrm{a}}$ & $85.3^{\mathrm{a}}$ & $303.7^{\mathrm{ab}}$ & $-37.6^{\mathrm{a}}$ & $-110.4^{\mathrm{C}}$ & $-19.6^{\mathrm{a}}$ & $-69.3^{\mathrm{a}}$ & $-53.4^{\mathrm{ab}}$ & $-55.7^{\mathrm{ab}}$ \\
\hline 25 & $\mathrm{HD}$ & $7.0^{\mathrm{ab}}$ & $15.4^{\mathrm{ab}}$ & $12.8^{\mathrm{a}}$ & $3.3^{\mathrm{a}}$ & $67.4^{\mathrm{a}}$ & $494.3^{\mathrm{ab}}$ & $-13.0^{\mathrm{a}}$ & $-47.7^{\mathrm{abc}}$ & $5.7^{\mathrm{a}}$ & $-8.0^{\mathrm{a}}$ & $-20.3^{\mathrm{ab}}$ & $-154.4^{\mathrm{ab}}$ \\
\hline 50 & LD & $7.3^{\mathrm{ab}}$ & $18.7^{\mathrm{ab}}$ & $10.2^{\mathrm{a}}$ & $3.7^{\mathrm{a}}$ & $96.2^{\mathrm{a}}$ & $444.7^{\mathrm{ab}}$ & $-21.5^{\mathrm{a}}$ & $-83.9^{b c}$ & $15.5^{\mathrm{a}}$ & $-22.4^{\mathrm{a}}$ & $-77.5^{\mathrm{ab}}$ & $-128.9^{a b}$ \\
\hline 50 & MD & $7.6^{\mathrm{ab}}$ & $14.4^{\mathrm{ab}}$ & $12.6^{\mathrm{a}}$ & $3.8^{\mathrm{a}}$ & $90.3^{\mathrm{a}}$ & $455.3^{\mathrm{ab}}$ & $-23.4^{\mathrm{a}}$ & $-38.7^{a b}$ & $-11.7^{\mathrm{a}}$ & $-24.2^{\mathrm{a}}$ & $-63.4^{\mathrm{ab}}$ & $-132.3^{a b}$ \\
\hline 50 & HD & $13.9^{\mathrm{ab}}$ & $18.6^{\mathrm{ab}}$ & $9.4^{\mathrm{a}}$ & $4.5^{\mathrm{a}}$ & $99.8^{\mathrm{a}}$ & $293.7^{\mathrm{ab}}$ & $-6.7^{\mathrm{a}}$ & $-84.9^{\mathrm{bc}}$ & $19.6^{\mathrm{a}}$ & $-51.6^{\mathrm{a}}$ & $-89.8^{b}$ & $-53.8^{\mathrm{ab}}$ \\
\hline 75 & LD & $8.4^{\mathrm{ab}}$ & $13.8^{\mathrm{b}}$ & $9.3^{\mathrm{a}}$ & $3.5^{\mathrm{a}}$ & $83.6^{\mathrm{a}}$ & $534.3^{\mathrm{a}}$ & $-35.8^{a}$ & $-35.5^{\mathrm{ab}}$ & $36.5^{\mathrm{a}}$ & $-13.9^{a}$ & $-51.5^{\mathrm{ab}}$ & $-174.4^{\mathrm{b}}$ \\
\hline 75 & MD & $8.2^{\mathrm{ab}}$ & $12.1^{\mathrm{b}}$ & $11.4^{\mathrm{a}}$ & $3.4^{\mathrm{a}}$ & $77.5^{\mathrm{a}}$ & $456.0^{\mathrm{ab}}$ & $-35.1^{a}$ & $-19.5^{a b}$ & $22.3^{\mathrm{a}}$ & $-12.8^{a}$ & $-40.9^{\mathrm{ab}}$ & $-138.3^{a b}$ \\
\hline 75 & HD & $7.3^{\mathrm{ab}}$ & $15.6^{\mathrm{ab}}$ & $9.7^{\mathrm{a}}$ & $3.4^{\mathrm{a}}$ & $85.7^{\mathrm{a}}$ & $394.0^{\mathrm{ab}}$ & $-21.8^{\mathrm{a}}$ & $-52.1^{\mathrm{abc}}$ & $36.2^{\mathrm{a}}$ & $-11.0^{\mathrm{a}}$ & $-56.3^{\mathrm{ab}}$ & $-106.7^{\mathrm{ab}}$ \\
\hline
\end{tabular}

Influence of swath density on mineral content of corn stover. Data are pooled over rainfall amount

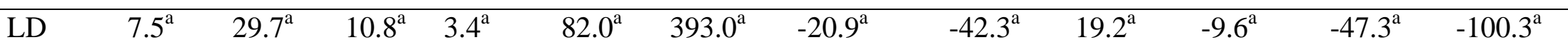




\begin{tabular}{|c|c|c|c|c|c|c|c|c|c|c|c|c|}
\hline $\mathrm{MD}$ & $10.0^{\mathrm{a}}$ & $15.1^{\mathrm{a}}$ & $12.2^{\mathrm{a}}$ & $3.9^{\mathrm{a}}$ & $75.0^{\mathrm{a}}$ & $366.2^{\mathrm{a}}$ & $-24.5^{\mathrm{a}}$ & $-45.7^{\mathrm{a}}$ & $0.3^{\mathrm{a}}$ & $-28.1^{\mathrm{a}}$ & $-35.5^{\mathrm{a}}$ & $-88.7^{\mathrm{a}}$ \\
\hline HD & $8.6^{\mathrm{a}}$ & $16.0^{\mathrm{a}}$ & $11.9^{\mathrm{a}}$ & $3.6^{\mathrm{a}}$ & $78.0^{\mathrm{a}}$ & $407.5^{\mathrm{a}}$ & $-10.3^{a}$ & $-56.6^{\mathrm{a}}$ & $7.8^{\mathrm{a}}$ & $-19.9^{\mathrm{a}}$ & $-43.8^{\mathrm{a}}$ & $-112.3^{a}$ \\
\hline
\end{tabular}

\begin{tabular}{|c|c|c|c|c|c|c|c|c|c|c|c|c|}
\hline 8 & $6.5^{\mathrm{a}}$ & $12.8^{\mathrm{b}}$ & $12.6^{\mathrm{a}}$ & $3.2^{\mathrm{a}}$ & $58.1^{\mathrm{b}}$ & $328.1^{\mathrm{a}}$ & $-6.0^{\mathrm{a}}$ & $-24.7^{\mathrm{a}}$ & $-2.7^{\mathrm{a}}$ & $5.5^{\mathrm{a}}$ & $-5.2^{\mathrm{a}}$ & $-69.7^{\mathrm{a}}$ \\
\hline 25 & $10.7^{\mathrm{a}}$ & $17.1^{\mathrm{a}}$ & $13.0^{\mathrm{a}}$ & $3.9^{\mathrm{a}}$ & $77.5^{\mathrm{ab}}$ & $368.1^{\mathrm{a}}$ & $-20.1^{\mathrm{ab}}$ & $-63.3^{\mathrm{ab}}$ & $-0.4^{\mathrm{a}}$ & $-25.9^{\mathrm{a}}$ & $-37.2^{\mathrm{ab}}$ & $-87.3^{\mathrm{a}}$ \\
\hline 50 & $9.6^{\mathrm{a}}$ & $17.3^{\mathrm{a}}$ & $10.7^{\mathrm{a}}$ & $4.0^{\mathrm{a}}$ & $95.4^{\mathrm{a}}$ & $397.9^{a}$ & $-17.2^{\mathrm{ab}}$ & $-69.1^{b}$ & $7.8^{\mathrm{a}}$ & $-32.7^{\mathrm{a}}$ & $-76.9^{b}$ & $-105.0^{\mathrm{a}}$ \\
\hline 75 & $8.0^{\mathrm{a}}$ & $13.8^{\mathrm{ab}}$ & $10.1^{\mathrm{a}}$ & $3.4^{\mathrm{a}}$ & $82.3^{\mathrm{ab}}$ & $461.4^{\mathrm{a}}$ & $-30.9^{b}$ & $-35.7^{\mathrm{ab}}$ & $31.6^{\mathrm{a}}$ & $-12.6^{\mathrm{a}}$ & $-49.5^{\mathrm{ab}}$ & $-139.8^{\mathrm{a}}$ \\
\hline
\end{tabular}

${ }^{\mathrm{Z}}$ Means within columns followed by different letters are significantly different at the 95\% confidence level. LD, MD, and HD is defined as low density, medium density, and high density, respectively. $* \%$ change is calculated by formulae, $\% C h a n g e=\frac{C_{i} \times D M_{i}-C_{f} \times D M_{f}}{C_{i} \times D M_{i}} \times$ 100 ,where, $C$ and DM are the concentration and dry matter of the constituent being analysed, and subscriptsi and $f$ are the initial and final values 